\title{
COMO AS OPERAÇÕES URBANAS CONSORCIADAS RESOLVEM A QUESTÃO HABITACIONAL: REFLEXÕES A PARTIRDOS CASOS ÁGUA ESPRAIADA (SP) E PORTO MARAVILHA (RJ)
}

\author{
HOW URBAN CONSORTIUM OPERATIONS SOLVE THE HOUSING ISSUE: REFLECTIONS FROM \\ THE CASES ÁGUAESPRAIADA (SP) AND PORTO MARAVILHA (RJ)
}

\author{
Alvaro Luis dos Santos Pereira ${ }^{1}$ \\ Paula Custódio de Oliveira²
}

\section{Resumo}

Este artigo tem como objetivo analisar o tratamento conferido à questão da habitacional de interesse social no âmbito de intervenções urbanísticas de grande porte implementadas por meio do instrumento da operação urbana consorciada. A estratégia metodológica adotada consiste no estudo em profundidade de dois casos emblemáticos de experiências desse tipo: a Operação Urbana Consorciada Água Espraiada, em São Paulo, e o Projeto Porto Maravilha, no Rio de Janeiro. Busca-se demonstrar a existência de uma dissociação entre os compromissos formalmente assumidos pelo poder público em legislações e discursos no sentido da promoção do direito à moradia e as práticas efetivamente adotadas no âmbito desses projetos urbanos, marcadas pelo contraste entre remoções de grande magnitude e ações de provisão habitacional de caráter incipiente. A pesquisa realizada envolveu a identificação e sistematização dos dispositivos referentes à moradia na legislação específica desses projetos, a análise de discursos sobre a questão habitacional proferidos por representantes do poder público diretamente envolvidos em sua

\footnotetext{
${ }^{1}$ Atua como Professor Adjunto da área de Direito, sub-área de Fundamentos de Direito Público, da Escola Paulista de Política, Economia e Negócios da Univerisdade Federal de São Paulo (EPPEN/Unifesp). Realizou programa de pós-doutorado na Faculdade de Arquitetura e Urbanismo da Universidade de São Paulo (FAUUSP). É doutor pela Faculdade de Direito da Universidade de São Paulo (FDUSP). Universidade Federal de São Paulo $\quad-\quad$ Brsil. http://orcid.org/0000-0002-7072-4851 E-mail: alvarolsp@yahoo.com

${ }_{2}$ Arquiteta urbanista formada pela FAUUSP e mestre em Planejamento Urbano e Regional pela mesma instituição. Integrou a equipe de relatoria do processo participativo de revisão do Plano Diretor de São Paulo (Lei 16.050/14). Desde 2013 é pesquisadora do Laboratório de Habitação e Assentamentos Humanos (LABHAB) da FAUUSP, no qual participou dos projetos Manejo de Águas Pluviais em Meio Urbano e Responsabilidade pública frente aos moradores em intervenções de renovação urbana / Public accountability to residents in contractual urban redevelopment (PARCOUR), ambos coordenados pela prof. Maria Lucia Refinetti Martins. É membro-fundador do coletivo LabLaje. Universidade de São Paulo - Brasil. E-mail: pcoliveira.9@gmail.com
} 
implementação, a análise da dinâmica dos processos de remoção e a identificação das medidas concretas de provisão habitacional em curso nesses projetos.

Palavras-chave: direito à moradia, operação urbana consorciada, habitação de interesse social, remoções, conflitos urbanos

\section{Abstract}

This article aims to analyze the way in which social housing is addressed in the context of large urban interventions implemented through the planning instrument called consorted urban operation. The methodological strategy adopted consists of the in-depth study of two emblematic cases of such experiences: the Consorted Urban Operation Água Espraiada in São Paulo and the Porto Maravilha Project in Rio de Janeiro. It seeks to demonstrate the existence of a gap between the commitments formally assumed by the public sector in legislations and discourses in the sense of promoting the right to housing and the practices effectively adopted in the context of these urban projects, marked by the contrast between massive removals and housing provision actions of small scale. The research carried out involved the identification and systematization of the housingrelated provisions in the specific legislation of these projects, the analysis of housing-related speeches delivered by representatives of the public sector directly involved in their implementation, the analysis of the dynamics of the removal processes and the identification of the concrete measures of housing provision in progress in these projects.

Keywords: right to housing, consorted urban operation, social housing, removals, urban conflicts.

\section{Introdução}

As grandes cidades brasileiras vêm passando por um processo de proliferação de intervenções urbanísticas de grande porte ao longo das últimas décadas. Tais projetos supostamente estratégicos para o desenvolvimento das cidades onde são promovidos - costumam abranger conjuntos amplos e bastante diversificados de diretrizes e ações específicas sobre o território. Nas disposições normativas e publicações oficiais relativas a projetos desse perfil, podese encontrar, com frequência, a alusão a um rol extenso de carências, necessidades e aspirações sociais relacionadas à conformação do espaço urbano que, em tese, pretende-se atender por meio de sua implementação, tais como a qualificação de redes de infraestrutura, saneamento e 
mobilidade, a melhoria de serviços públicos, a ampliação da oferta de espaços públicos e equipamentos culturais, a reurbanização de assentamentos precários, a provisão de moradia acessível à população de baixa renda, a ampliação da oferta de emprego e de outras formas de geração de renda, e assim por diante. Para se mitigar eventuais resistências e viabilizar politicamente a implementação desses projetos, costuma-se acenar com um pacote razoavelmente generoso de ações de cunho redistributivo, as quais compensariam seus impactos socioespaciais potencialmente excludentes. A provisão de moradia popular costuma figurar como um dos principais componentes desse rol de medidas de natureza compensatória.

As propostas de transformação urbanística trazidas por tais projetos, entretanto, costumam ser expressas de modo substancialmente genérico em disposições normativas, publicações e discursos de agentes governamentais, de modo que as decisões sobre o que será efetivamente implementado, quando e em que magnitude acabam sendo quase que integralmente remetidas ao momento de sua implementação. Sua formatação jurídica define de modo bastante vago - quando define - aspectos como o percentual de investimentos a ser destinado para habitação, as metas quantitativas de oferta habitacional, as condições de atendimento a moradores removidos em função do projeto e os órgãos responsáveis. As experiências recentes vêm mostrando que, de modo recorrente, as já incipientes ações compensatórias previstas nesses projetos permanecem como promessas não realizadas, figurando fundamentalmente como elementos de estratégias discursivas empregadas para se alcançar sua viabilidade política.

Este trabalho apresenta um estudo do tratamento conferido à questão habitacional em dois casos paradigmáticos de intervenção urbanística de grande porte promovidas nas duas maiores cidades brasileiras: a Operação Urbana Consorciada Água Espraiada (OUCAE), iniciada em São Paulo em 2001; e a Operação Urbana Consorciada da Região do Porto do Rio de Janeiro (OUCPRJ), conhecida como "Porto Maravilha", iniciada em 2009. Analisaremos o que foi estabelecido inicialmente como objetivos e diretrizes no tocante à provisão habitacional, a dinâmica dos processos de remoção associados à sua implementação e as ações de provisão habitacional efetivamente implementadas em cada um desses projetos.

O artigo está dividido em três seções além desta introdução. A segunda seção traz algumas considerações gerais sobre o surgimento das operações urbanas e seu modo de funcionamento. Com suporte em alguns trabalhos que se tornaram referência no debate sobre o tema, a seção busca delinear, ainda que de modo bastante sintético, os termos em que vem sendo travado o debate sobre esta temática na literatura acadêmica. A terceira seção apresenta um panorama dos compromissos referentes à questão habitacional assumidos por parte de agentes governamentais 
no âmbito desses dois projetos. O levantamento foi realizado a partir da análise das leis e decretos específicos desses projetos, dos respectivos prospectos, de outros materiais divulgados por órgãos governamentais e de declarações públicas de autoridades diretamente envolvidas em sua implementação. A quarta seção apresenta um relato sobre a dinâmica concreta de condução da questão habitacional nesses projetos, fazendo um balanço sobre as remoções e as ações de provisão habitacional efetivamente implementadas. A análise foi construída com base na leitura de publicações governamentais e relatórios de pesquisa em que os referidos casos foram objetos de estudo, na realização de entrevistas com moradores e outros atores relevantes e na realização de visitas de campo.

\section{A "fórmula mágica": o mito do custeio de projetos urbanos e habitacionais por meio da} transformação do potencial construtivo em ativo financeiro

As operações urbanas consorciadas valem-se de uma engenharia financeira aparentemente benéfica para todos os segmentos sociais e agentes por elas afetados, sendo frequentemente caracterizadas em discursos como uma fórmula conveniente tanto do ponto de vista da gestão pública municipal, como do setor imobiliário e da população urbana em geral ${ }^{3}$. A municipalidade altera as normas gerias de zoneamento em lugares específicos da cidade por meio da aprovação de leis específicas, estabelecendo regulações flexíveis quanto ao potencial construtivo e aos tipos de uso do solo admitidos. Empreendedores imobiliários interessados em obter os chamados direitos urbanísticos adicionais, que podem envolver acréscimos de potencial construtivo ou mudanças de tipo de uso, pagam contrapartidas ao poder público municipal, conforme os parâmetros de cálculo previstos em legislação específica. Os recursos auferidos com a cobrança pela outorga dos direitos urbanísticos adicionais, por sua vez, são reinvestidos no custeio de melhorias de infraestrutura, equipamentos urbanos e serviços no local.

\footnotetext{
${ }^{3}$ A pesquisa feita pela urbanista Mariana Fix sobre as operações urbanas na época em que se concluía o processo de formulação da Operação Urbana Consorciada Água Espraiada (OUCAE), no início da década de 2000, chamou atenção para a força persuasiva dos discursos feitos em defesa desse instrumento, razão pela qual a autora qualificou-as, metaforicamente, como uma "fórmula mágica". Os estudos empíricos feitos pela autora sobre experiências concretas de operação urbana na cidade de São Paulo desafiaram algumas das principais afirmações pressentes nos discursos mais elogiosos a respeito desse instrumento, tendo se tornado referência para a reflexão crítica sobre o tema. Ver FIX (2000; 2001).
} 
Essa sistemática seria uma forma de concertação entre os setores público e privado em que, hipoteticamente, ambos sairiam ganhando ${ }^{4}$. Para o poder público, seria uma alternativa ao uso de recursos orçamentários convencionais, permitindo-Ihe viabilizar ações de qualificação urbanística mesmo num contexto de restrição fiscal. Da perspectiva de agentes do setor imobiliário, tal mecanismo permitiria flexibilizar controles urbanísticos e restrições ao direito de construir em áreas cobiçadas, bem como centralizar um volume de investimentos capaz de impulsionar transformações urbanas significativas nessas localidades, favorecendo a dinamização de seu ambiente de negócios. A população da cidade em geral, por sua vez, seria beneficiada de duas maneiras. Em primeiro lugar, pelo potencial aumento na oferta de empregos e de outras formas de geração de renda decorrentes da dinamização do setor imobiliário 5 . Em segundo lugar, pelo fato de práticas desse tipo proporcionarem um aumento dos recursos que poderiam ser destinados ao custeio de demandas sociais como habitação, transporte público, saneamento básico, equipamentos culturais, entre outras. É precisamente a perspectiva de atendimento a demandas como essas o que confere poder de persuasão às estratégias discursivas de legitimação das operações urbanas.

A prática de se recorrer à monetização do potencial construtivo como fonte de recurso para o financiamento de políticas urbanas remete a um contexto anterior ao surgimento do instrumento da "operação urbana consorciada" em sua formatação atual ${ }^{6}$. Podem-se mencionar, inicialmente, experiências de cobrança pela outorga de potencial construtivo adicional como estratégia de arrecadação suplementar utilizada por governos locais em períodos anteriores. Já no final dos anos 1980, num contexto em que se combinavam fatores como a emergência da crise fiscal do Estado, a ascensão do movimento pela reforma urbana e a profusão de instrumentos urbanísticos concebidos por governos locais progressistas ${ }^{7}$, surgiram modalidades mais próximas do que viria a ser a

\footnotetext{
${ }^{4}$ Para uma caracterização do instrumento da operação urbana como alternativa à crise de financiamento do poder público local que, em tese, poderia exercer papel positivo na busca por cidades mais justas e inclusivas, ver ALFONSIN (2008) e SANDRONI (2001).

5 A metáfora da cidade como máquina de crescimento, formulada originalmente pelos sociólogos estadunidenses John Logan e Harvey Molocht e amplamente disseminada no campo dos estudos urbanos, oferece uma boa imagem-síntese da economia política da produção do espaço no capitalismo contemporâneo. Embora a elaboração teórica e o tom crítico do pensamento desses autores não estejam presentes em discursos de senso comum relacionados à temática do desenvolvimento urbano, podem-se encontrar, nesses últimos, raciocínios com vários pontos em comum com a ideias desenvolvidas pelos autores. Ver LOGAN \& MOLOCHT (1987).

${ }^{6}$ Para uma perspectiva histórica sobre a concepção dos chamados instrumentos de captura da valorização imobiliária e o surgimento das operações urbanas consorciadas, ver NOBRE (2009); MONTANDON (2009); e FIX (2000).

${ }^{7}$ Para uma reflexão sobre o período mencionado e um balanço crítico a respeito da trajetória do movimento da reforma urbana, suas realizações e limites, ver ROLNIK (2009) e KLINK \& DENALDI (2016).
} 
operação urbana consorciada, como por exemplo as operações interligadas do governo petista de Luíza Erundina (1898-1992). Aquele instrumento envolvia a captação de recursos por meio da cobrança pela outorga de potencial construtivo adicional em áreas de interesse do mercado imobiliário e sua destinação ao custeio de ações de reurbanização de assentamentos precários e provisão habitacional em outras áreas da cidade, razão pelo qual eram chamadas de 'interligadas'.

Além da questão terminológica, esse mecanismo antecipava outro traço fundamental das operações urbanas: a presença de uma racionalidade territorial. Ao invés de ser um simples mecanismo arrecadatório - como acontece com a outorga onerosa comum, em que os recursos arrecadados fluem para fundos municipais que realizam investimentos não obrigatoriamente destinados a porções específicas do território - as operações interligadas eram concebidas como uma espécie de subsídio cruzado espacial, figurando como uma forma de tributação que incidia sobre a produção imobiliária em áreas mais afluentes para financiar ações de cunho redistributivo em áreas mais carentes.

O fluxo territorial dos recursos é precisamente o ponto de virada das operações urbanas consorciadas em relação às operações "interligadas". A principal mudança trazida por este instrumento em relação às práticas anteriores de captação de recursos por meio de transações envolvendo o direito de construir é o reinvestimento obrigatório dos valores arrecadados na mesma área em que estes são captados, ou seja, no interior de um perímetro legalmente definido como área passível de outorga de potencial construtivo adicional. Dessa forma, ao invés de funcionar como base para a promoção de subsídios cruzados entre áreas ricas e pobres, a cobrança do potencial construtivo torna-se um dispositivo de retroalimentação de espirais de valorização imobiliária em fragmentos urbanos específicos.

Nas apologias feitas ao uso dessa modalidade de financiamento de intervenções urbanas, alega-se que ações de cunho redistributivo não deixariam de estar presentes nas operações urbanas, uma vez que poderiam ser realizadas no interior de seu perímetro. A provisão de habitação de interesse social (HIS) seria uma das principais formas de realização de promessas nesse sentido, sendo invariavelmente apresentada como diretriz em legislações, publicações governamentais e discursos de gestores públicos relacionados a esses projetos. Entretanto, como buscaremos mostrar, existem tensões entre a promoção de ações de cunho redistributivo e o funcionamento da engrenagem financeira de uma operação urbana que fazem com que, na prática, as primeiras tendam a permanecer como meras promessas. 


\section{O tratamento da questão habitacional no âmbito legal e discursivo nas operações} urbanas

\subsection{Disposições sobre habitação na Operação Urbana Consorciada Água Espraiada}

No caso da Operação Urbana Consorciada Água Espraiada (OUCAE), há um conflito bastante explícito entre o plano de intervenções proposto e a questão habitacional. A região é marcada pela presença de um conjunto numeroso de ocupações populares bastante consolidadas, que muitas vezes se sobrepõem às áreas de implantação de intervenções urbanísticas, o que impossibilita a realização das obras idealizadas sem a remoção de um número expressivo de moradores. Por esta razão, a questão habitacional constitui um elemento bastante determinante para a viabilização política do projeto.

A afirmação de um compromisso público de atendimento a demandas habitacionais manifesta-se de diferentes maneiras na estratégia de legitimação desta operação urbana, permeando disposições normativas, publicações governamentais e discursos de gestores públicos. Essa preocupação aparece de modo sistemático na legislação da OUCAE, estando presente na Lei 13.260/2001, que instituiu a operação urbana, nas Leis 15.416/2011 e 16.975/2018, que introduziram modificações ao projeto inicial, assim como nos Decretos 42.898/2003, 44.845/2004 e 53.364/2012, que a regulamentaram. Em linhas gerais, a referida legislação prevê, como princípios e objetivos gerais do projeto, a ampliação da oferta de habitação de interesse social (HIS), a reurbanização de assentamentos precários, a criação de condições para a permanência da população de baixa renda na região, o reassentamento de moradores atingidos por remoção no interior do perímetro da operação urbana, entre outros (ver Tabela 1).

Disposições mais concretas foram introduzidas mais recentemente pela Lei 15.416/2011, que previu a destinação obrigatória de $10 \%$ dos recursos auferidos com a venda de CEPACs (Certificados de Potencial Adicional de Construção) para HIS, percentual que foi elevado para 30\% após a aprovação da Lei 16.975/2018. Além das disposições previstas na legislação específica, vale ressaltar a existência de várias zonas especiais de interesse social (ZEIS) - demarcadas pelo Plano Diretor Estratégico (PDE) de 2014, sendo algumas delas estabelecidas desde o PDE de 2004 -, no interior do perímetro de intervenção, o que reforça a existência de um compromisso formal por parte do Poder Público com as demandas habitacionais.

Tabela 1. Principais disposições sobre habitação na legislação específica da OUCAE. Fonte: elaboração própria a partir da Lei 13.260/2001(grifos nossos). 


\begin{tabular}{|c|c|c|}
\hline Norma & $\begin{array}{c}\text { Capítulo/Seçã } \\
0\end{array}$ & Principais disposições relacionadas à questão habitacional \\
\hline \multirow[t]{4}{*}{$\begin{array}{l}\text { Lei } \\
13.260 / 200 \\
1\end{array}$} & $\begin{array}{l}\text { Capítulo I - Do } \\
\text { Conceito e Do } \\
\text { Programa de } \\
\text { Intervenções } \\
\text { Seção I - Do } \\
\text { Conceito }\end{array}$ & $\begin{array}{l}\text { Art. } 2^{\circ} \text {. Com o objetivo de tratar de forma diferenciada as } \\
\text { desigualdades existentes na região e privilegiando as funções } \\
\text { urbanas relacionadas com a distribuição espacial da } \\
\text { população, das atividades econômicas e sociais, da oferta de } \\
\text { infra-estrutura e de serviços urbanos, são criados os } \\
\text { seguintes setores: } \\
\text { (...) } \\
\text { VII - SETOR ZEIS, considerado ZONA ESPECIAL DE INTERESSE } \\
\text { SOCIAL, tendo como objetivo a consolidação das famílias } \\
\text { moradoras e a produção de Habitações de Interesse Social }\end{array}$ \\
\hline & $\begin{array}{l}\text { Capítulo I - Do } \\
\text { Conceito e Do } \\
\text { Programa de } \\
\text { Intervenções } \\
\text { Seção II - Do } \\
\text { Programa de } \\
\text { Intervenções }\end{array}$ & $\begin{array}{l}\text { Art. 3‥ O Programa de Intervenções, garantindo o pleno } \\
\text { desenvolvimento urbano e preservando a qualidade } \\
\text { ambiental da região, tem por objetivo a complementação do } \\
\text { sistema viário e de transportes, priorizando o transporte } \\
\text { coletivo, a drenagem, a oferta de espaços livres de uso } \\
\text { público com tratamento paisagístico e o provimento de } \\
\text { Habitações de Interesse Social para a população moradora } \\
\text { em favelas atingida pelas intervenções necessárias, e será } \\
\text { realizado através das seguintes obras e intervenções: } \\
\text { (...) } \\
\text { III - Implantação de unidades de Habitação de Interesse } \\
\text { Social - HIS, melhoramentos e reurbanização, assegurando- } \\
\text { se o reassentamento definitivo das famílias atingidas pelas } \\
\text { obras e outras intervenções previstas nesta lei, no } \\
\text { perímetro desta Operação Urbana Consorciada (Redação } \\
\text { acrescida pela Lei no. 16.975/2018) }\end{array}$ \\
\hline & $\begin{array}{l}\text { Capítulo II - } \\
\text { Dos Objetivos } \\
\text { e Das } \\
\text { Diretrizes } \\
\text { Seção I - Dos } \\
\text { Objetivos e } \\
\text { Das Diretrizes } \\
\text { Gerais }\end{array}$ & $\begin{array}{l}\text { Art. 40. A Operação Urbana Consorciada Água Espraiada tem } \\
\text { como objetivos gerais: } \\
\text { (...) } \\
\text { II - Desenvolver um programa que garanta o atendimento à } \\
\text { população que vive em habitações subnormais, atingida } \\
\text { pelas intervenções urbanísticas previstas nesta lei, em } \\
\text { conjunto com os órgãos municipais, estaduais e federais } \\
\text { competentes, com implantação de unidades de Habitação } \\
\text { de Interesse Social, melhoramentos e reurbanização; }\end{array}$ \\
\hline & $\begin{array}{l}\text { Capítulo II - } \\
\text { Dos Objetivos }\end{array}$ & $\begin{array}{l}\text { Art. 7‥ Nos setores de implantação de Habitações de } \\
\text { Interesse Social - HIS, no âmbito desta Operação Urbana }\end{array}$ \\
\hline
\end{tabular}




\begin{tabular}{|c|c|}
\hline $\begin{array}{l}\text { e Das } \\
\text { Diretrizes } \\
\text { Seção II - Das } \\
\text { Diretrizes } \\
\text { Específicas }\end{array}$ & $\begin{array}{l}\text { Consorciada, deverão ser previstos usos complementares à } \\
\text { função habitacional, bem como espaços públicos. }\end{array}$ \\
\hline $\begin{array}{l}\text { Capítulo III - } \\
\text { Dos Meios, } \\
\text { Recursos e } \\
\text { Contrapartidas } \\
\text { da Operação } \\
\text { Urbana } \\
\text { Consorciada } \\
\text { Água } \\
\text { Espraiada } \\
\text { Seção III - Das } \\
\text { Desapropriaçõ } \\
\text { es }\end{array}$ & $\begin{array}{l}\text { Art.15. A desocupação de imóveis, inclusive daqueles sob } \\
\text { locação, quando atingidos pelas intervenções urbanísticas } \\
\text { desta Operação Urbana Consorciada, deverá atentar para o } \\
\text { direito de permanência desses moradores na região e, no } \\
\text { caso de locatários, ao direito de acomodação em condições } \\
\text { dignas até sua incorporação em Programas Habitacionais. }\end{array}$ \\
\hline $\begin{array}{l}\text { Capítulo IV - } \\
\text { Do Grupo de } \\
\text { Gestão }\end{array}$ & $\begin{array}{l}\text { Art. 22. Os recursos auferidos pela Operação Urbana } \\
\text { Consorciada Água Espraiada serão administrados pela } \\
\text { Empresa Municipal de Urbanização - EMURB através de conta } \\
\text { vinculada à presente Operação, a ser regulamentada por } \\
\text { Decreto. } \\
\text { (...) } \\
\text { §5o Deverão ser obrigatoriamente aplicados na construção } \\
\text { de Habitações de Interesse Social - HIS no mínimo } 10 \% \text { (dez } \\
\text { por cento) da receita obtida com a alienação de Certificados } \\
\text { de Potencial Adicional de Construção - CEPAC. (Redação } \\
\text { acrescida pela Lei no. 15.416/2011, revogada pela Lei } \\
\text { no. 16.975/2018) } \\
\text { §50 No mínimo 30\% (trinta por cento) dos recursos } \\
\text { arrecadados a partir da promulgação desta lei com a } \\
\text { alienação de CEPACs deverão ser aplicados em Habitação de } \\
\text { Interesse Social no perímetro de abrangência da Operação } \\
\text { Urbana Consorciada Água Espraiada, até o reassentamento } \\
\text { definitivo de todas as famílias previamente cadastradas e } \\
\text { atingidas pelas obras e outras intervenções previstas na Lei, } \\
\text { devendo o empenhamento dos recursos arrecadados a cada } \\
\text { leilão e destinados a essa finalidade ser efetuado em até } 5 \\
\text { (cinco) anos da sua data de realização (Redação dada pela Lei } \\
\text { no. 16.975/2018, em vigor) }\end{array}$ \\
\hline
\end{tabular}


Figura 1. Setores da Operação Urbana OUCAE (destaque para os perímetros de ZEIS, em roxo). Fonte: PMSP, Lei 13.260/2001

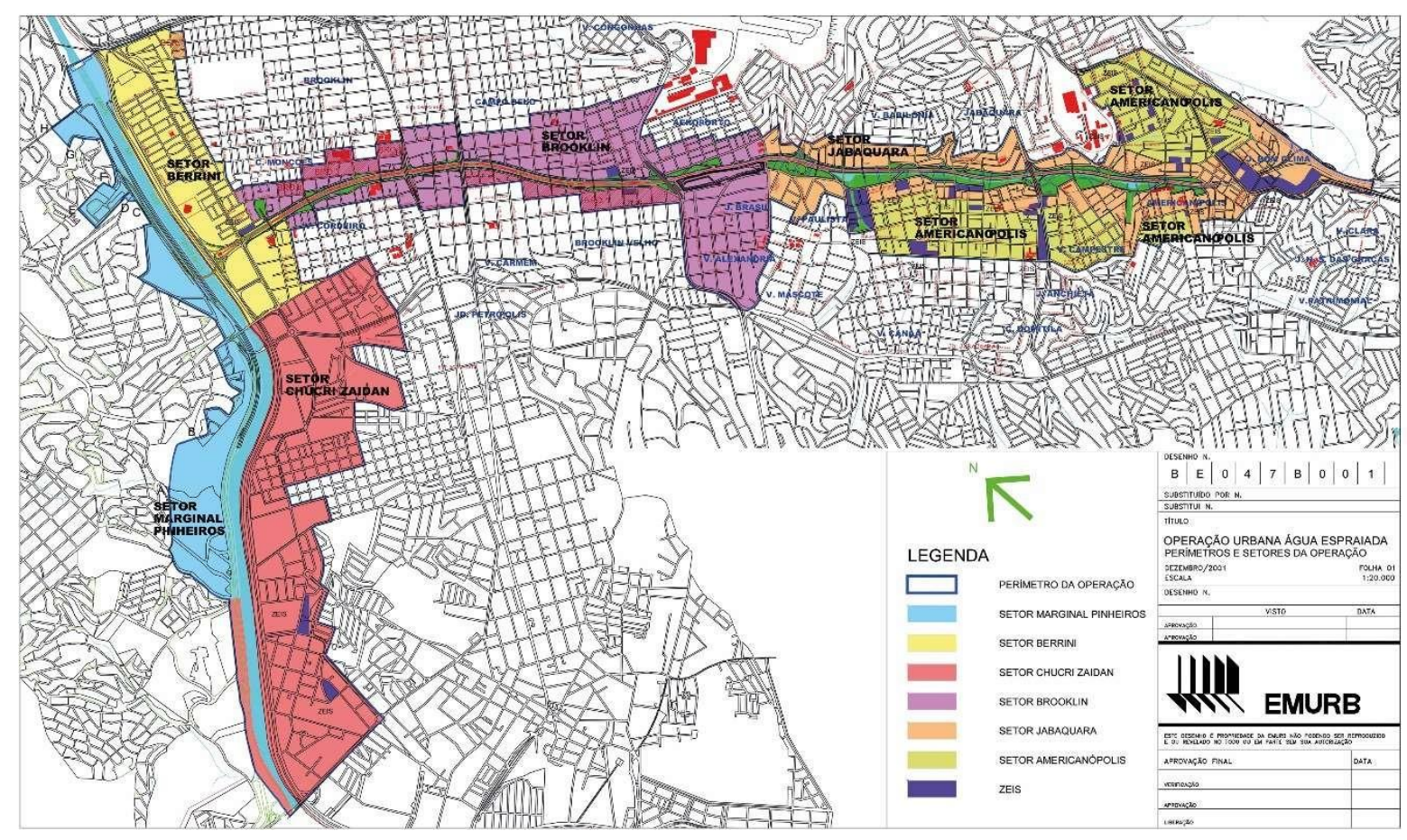

O compromisso do projeto com o atendimento habitacional aparece também no Prospecto de Registro da OUCAE, relatório preparado pela Prefeitura na ocasião do primeiro lançamento de CEPACs para o atendimento de disposições regulatórias expedidas pela Comissão de Valores Mobiliários (CVM). Este documento visa divulgar informações quanto aos objetivos, condições de viabilidade econômica e possíveis dificuldades e riscos do projeto, tendo como principal públicoalvo os potenciais investidores interessados em adquirir CEPACs. O Prospecto traz um maior detalhamento quanto às ações relacionadas à questão habitacional no projeto, estimando o número de famílias a serem removidas e elencando as formas de atendimento a serem oferecidas a elas. Nesse sentido: 
No que diz respeito às Intervenções de cunho social, a Operação Urbana Consorciada Água Espraiada pretende atender um número próximo a 8,5 mil famílias em situação de favela e que estão assentadas no interior das faixas de melhoramentos viários que formam parte da Operação Urbana Consorciada. Entre as formas de Intervenções sociais previstas estão a construção de unidades habitacionais; reurbanização de favelas, onde convier; pagamento em espécie àqueles que preferirem se mudar; ou ainda ao pagamento de até $\mathrm{R} \$ 7,5 \mathrm{mil}$ ao investidor privado por unidade habitacional a ser construída para efeitos de aquisição de terreno necessário à construção das habitações. (SÃO PAULO, 2004, pg. 58, grifo nosso)

A ênfase em questões sociais também pode ser observada em discursos proferidos por gestores públicos a respeito de projetos envolvendo o uso desse instrumento urbanístico. Nesse sentido, pode-se mencionar como exemplo uma fala do ex-Secretário Municipal de Infraestrutura Urbana e Obras, Roberto Garibe, na ocasião da entrega de um conjunto habitacional na região, ocorrida em outubro de 2015:

Nós estamos dentro de uma operação urbana que, mais do que obras, tem uma concepção de privilegiar a área social de tudo que tem que ser feito. Estas são as primeiras unidades habitacionais que estamos entregando e a regra é as pessoas continuarem a morar no lugar em que elas construíram seus laços de família e suas relações ${ }^{8}$ (grifo nosso).

\subsection{Disposições sobre habitação no Projeto Porto Maravilha}

Pode-se observar um cenário bastante semelhante no caso da Operação Urbana Consorciada da Região do Porto do Rio de Janeiro (OUCPRJ), o assim chamado "Porto Maravilha". Na legislação específica desta intervenção urbanística, podem-se encontrar disposições análogas às da OUCAE no tocante à questão habitacional, inclusive adotando-se terminologia praticamente idêntica. A Lei Complementar Municipal 101/2009 - lei que instituiu a operação urbana do Porto Maravilha - também prevê, entre suas diretrizes e objetivos principais, aspectos como o incentivo à ampliação de usos residenciais, a provisão de habitação de interesse social, a promoção de ações de regularização fundiária e o reassentamento de moradores afetados pelas ações englobadas no

\footnotetext{
${ }^{8}$ Essa passagem foi extraída de reportagem publicada na página eletrônica da Prefeitura Municipal de São Paulo. Prefeitura entrega moradias em área da Operação Urbana Água Espraiada, 14/10/2015, disponível em:

<http://www.capital.sp.gov.br/noticia/prefeitura-entrega-moradias-em-area-da-operacao> $\quad$ Acesso em $30 / 11 / 2018$.
} 
projeto prioritariamente no interior do seu perímetro. Algumas das principais disposições com esse teor podem ser observadas na Tabela 2.

Tabela 2. Principais disposições sobre habitação na legislação específica da OUCPRJ. Fonte: elaboração própria a partir da Lei Complementar Municipal 101/2009(grifos nossos).

\begin{tabular}{|c|c|c|}
\hline Norma & $\begin{array}{l}\text { Capítulo/Seção/Arti } \\
\text { go }\end{array}$ & $\begin{array}{c}\text { Principais disposições relacionadas à questão } \\
\text { habitacional }\end{array}$ \\
\hline $\begin{array}{l}\text { Lei } \\
\text { Complement } \\
\text { ar 101/2009 }\end{array}$ & $\begin{array}{l}\text { Capítulo I - Do } \\
\text { Objeto, Da Criação e } \\
\text { Da Delimitação da } \\
\text { Área de Especial } \\
\text { Interesse Urbanístico } \\
\text { da Região do Porto } \\
\text { do Rio de Janeiro }\end{array}$ & $\begin{array}{l}\text { Art. } 2^{\circ} \text { A Operação Urbana Consorciada tem por finalidade } \\
\text { promover a reestruturação urbana da AEIU, por meio da } \\
\text { ampliação, articulação e requalificação dos espaços livres } \\
\text { de uso público da região do Porto, visando à melhoria da } \\
\text { qualidade de vida de seus atuais e futuros moradores, e } \\
\text { à sustentabilidade ambiental e socioeconômica da região. } \\
\S 1^{\circ} \text { Os seguintes princípios nortearão o } \\
\text { planejamento, a execução e a fiscalização da Operação } \\
\text { Urbana Consorciada: } \\
\text { (...) } \\
\text { III - o atendimento econômico e social da } \\
\text { população diretamente afetada pela Operação; } \\
\text { IV - a promoção do adequado aproveitamento } \\
\text { dos vazios urbanos ou terrenos subutilizados ou ociosos; } \\
\text { V - a integração da área com a área central da } \\
\text { Cidade e o estímulo ao uso residencial, possibilitando } \\
\text { melhor aproveitamento da estrutura urbana existente; } \\
\text { (...) } \\
\text { VII - o apoiamento da regularização fundiária } \\
\text { urbana nos imóveis de interesse social; } \\
\text { (...) } \\
\text { XII- incentivar a recuperação de imóveis } \\
\text { trabalho e renda existentes na região; }\end{array}$ \\
\hline
\end{tabular}




\begin{tabular}{|c|c|}
\hline & $\begin{array}{l}\text { XIV - promover ações que assegurem a } \\
\text { sustentabilidade da população residente; } \\
\text { XV - promover as ações necessárias para o } \\
\text { reconhecimento e a regularização das comunidades } \\
\text { tradicionais. }\end{array}$ \\
\hline $\begin{array}{l}\text { Capítulo III - Do } \\
\text { Plano de Operação } \\
\text { Urbana Consorciada } \\
\text { e do Programa } \\
\text { Básico de Ocupação } \\
\text { da Área } \\
\text { Seção IV - Do } \\
\text { Atendimento } \\
\text { Econômico e Social } \\
\text { da População } \\
\text { Afetada }\end{array}$ & $\begin{array}{l}\text { Art. 29. O Poder Público desenvolverá um programa que } \\
\text { garanta o atendimento à população de baixa renda } \\
\text { atingida pelas intervenções urbanísticas previstas nesta } \\
\text { Lei Complementar, em conjunto com os órgãos } \\
\text { municipais, estaduais e federais competentes. } \\
\S 1 \text { A implantação de unidades habitacionais de } \\
\text { interesse social poderá ocorrer em todos os setores da } \\
\text { Operação Urbana Consorciada. } \\
\text { § } 2 \text { o A provisão de habitação de interesse social poderá } \\
\text { ser realizada por meio de soluções habitacionais que } \\
\text { assegurem o reassentamento da população residente } \\
\text { atingida pelas intervenções urbanísticas em áreas de } \\
\text { especial interesse social. }\end{array}$ \\
\hline $\begin{array}{l}\text { Capítulo III - Do } \\
\text { Plano de Operação } \\
\text { Urbana Consorciada } \\
\text { e do Programa } \\
\text { Básico de Ocupação } \\
\text { da Área } \\
\text { Seção IV - Do } \\
\text { Atendimento } \\
\text { Econômico e Social } \\
\text { da População } \\
\text { Afetada }\end{array}$ & $\begin{array}{l}\text { Art. 30. Recursos advindos da Operação citada no art. } 20 \\
\text { desta Lei Complementar, bem como de outras fontes de } \\
\text { financiamento disponíveis, poderão ser utilizados para o } \\
\text { desenvolvimento de ações e projetos dentro dos } \\
\text { programas habitacionais e outros de interesse social, no } \\
\text { atendimento da população atingida pelas intervenções } \\
\text { urbanísticas previstas nesta Lei Complementar. }\end{array}$ \\
\hline $\begin{array}{l}\text { Capítulo III - Do } \\
\text { Plano de Operação } \\
\text { Urbana Consorciada } \\
\text { e do Programa } \\
\text { Básico de Ocupação } \\
\text { da Área } \\
\text { Seção IV - Do } \\
\text { Atendimento } \\
\text { Econômico e Social }\end{array}$ & $\begin{array}{l}\text { Art.31. As comunidades e bairros da área afetada serão } \\
\text { incentivados a desenvolver processos participativos nos } \\
\text { termos do que dispõe o Estatuto da Cidade - Lei } 10.257 \text {, } \\
\text { de } 10 \text { de julho de } 2001 \text {, e observando os princípios da } \\
\text { Agenda } 21 \text { e as recomendações do Ministério das Cidades, } \\
\text { visando a elaboração de planos de desenvolvimento } \\
\text { sustentável locais. }\end{array}$ \\
\hline
\end{tabular}




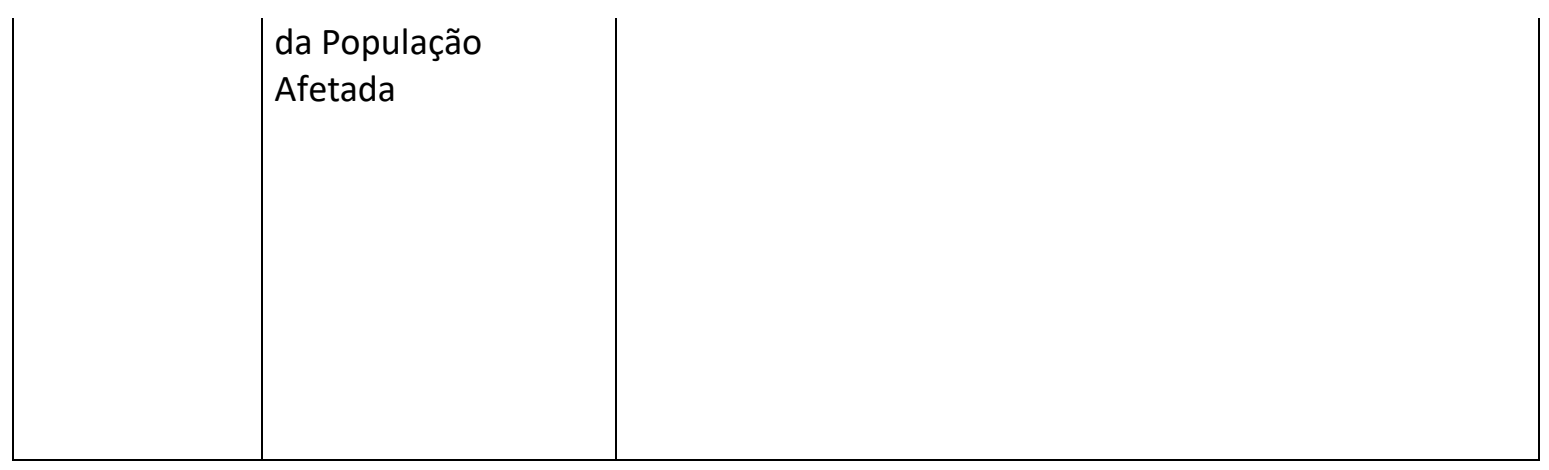

Da leitura desses trechos da lei, podem-se identificar algumas diretrizes que, supostamente, deveriam balizar essa intervenção urbanística, tais como o incentivo ao uso residencial e ao adensamento populacional; a regularização fundiária e urbanística de assentamentos populares; a reabilitação de moradias populares em condições precárias; a realização de programas visando à viabilização da permanência de populações tradicionais no local; e a sujeição das ações do Poder Público a um princípio de não remoção da população residente no local e de reassentamento de grupos eventualmente afetados por obras do projeto em áreas próximas. Tais orientações foram reiterados pelo Prospecto da OUCPRJ. Esse documento aponta como um dos objetivos específicos do projeto a promoção de melhorias nas favelas e assentamentos populares existentes nos morros da região, ressaltando que tais ações devem ser conduzidas de modo a se preservar a identidade sociocultural do local, bem como a se reassentar moradores que venham a ser removidos por motivo de risco em áreas próximas. Nesse sentido:

A ambiência dos morros (áreas de ocupação mais antiga) será preservada através da implantação de uma nova infraestrutura, bem como a recuperação da pavimentação dos seus espaços públicos. Os entornos de bens tombados tanto dos morros como das demais áreas receberão cuidados especiais [...] No que diz respeito à questão habitacional, está previsto o remanejamento gradual das habitações localizadas em área de risco existentes no Morro da Providência para novas residências localizadas em áreas do entorno, considerando o Projeto Novas Alternativas, da Prefeitura, e o Projeto Minha Casa Minha Vida, do Governo Federal (RIO DE JANEIRO, 2017, pp.26-27, grifo nosso).

Figura 2. Planta Geral de Intervenção, OUCPRJ. Fonte: CDURP - Companhia de Desenvolvimento Urbano da Região do Porto do Rio de Janeiro. 


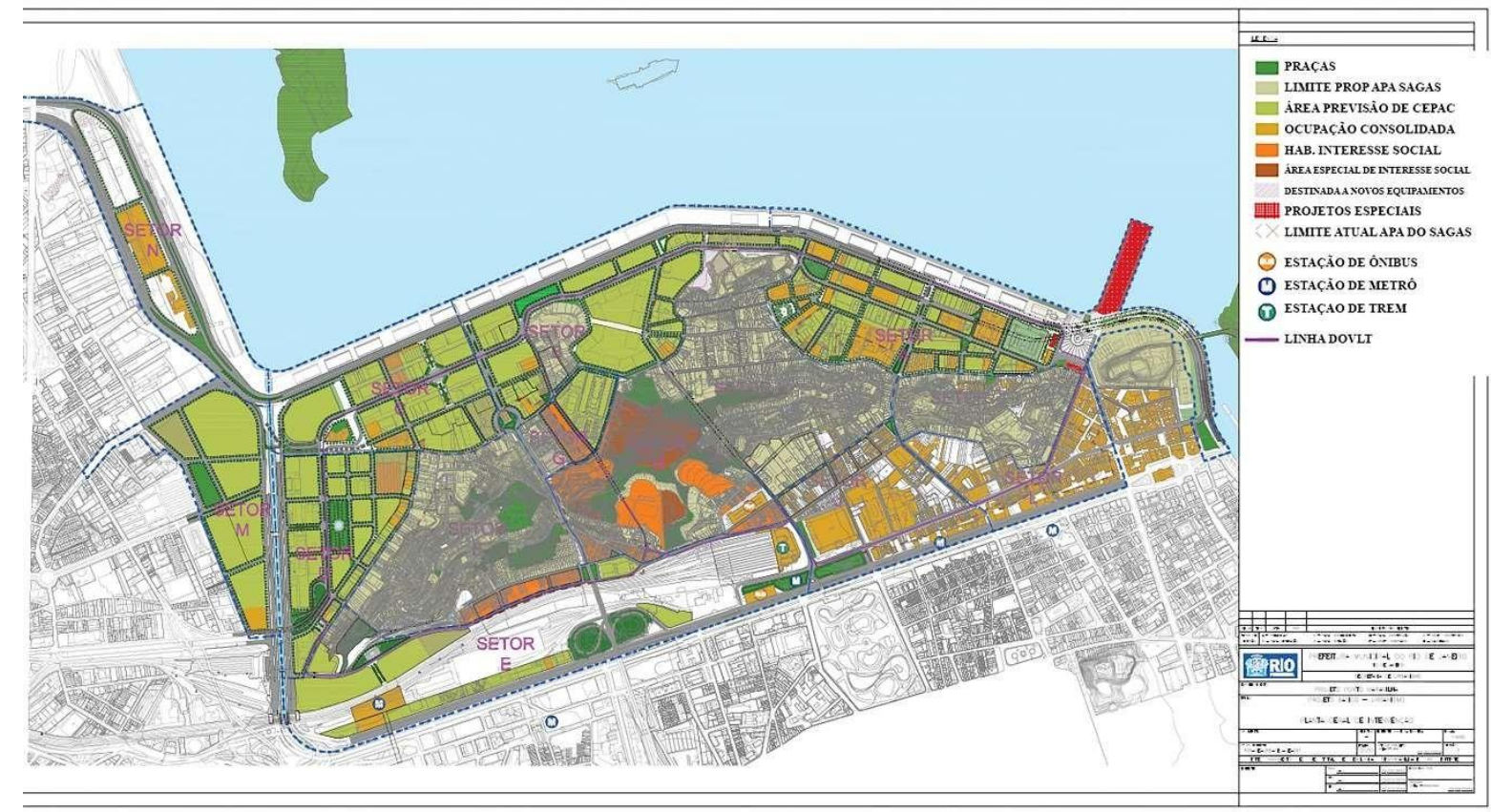

O alegado compromisso em se estimular o uso habitacional com a presença de diferentes faixas de renda na área pode ser observado também em falas de autoridades públicas à frente do projeto. $\mathrm{O}$ trecho a seguir, extraído de reportagem sobre o lançamento do Residencial Porto Vida (empreendimento imobiliário de grande porte lançado na região em 2013), que contou com a presença do ex-prefeito Eduardo Paes, ilustra a tônica de tais discursos. Em suas palavras:

Meu compromisso é o de garantir que a área seja ocupada com residenciais para todas as classes econômicas. O Porto Vida representa a reocupação da Região Portuária, lugar estratégico próximo ao Centro, onde a população poderá morar perto do trabalho [...] Lançamos um pacote para que os empreendedores privados invistam na região, e não só em prédios empresariais. A gente vai ter metade da área do Porto para residência. Mais que isso, teremos 2.200 novas habitações de interesse social, onde vamos fazer empreendimentos do Minha Casa, Minha Vida. Identificamos 42 terrenos que serão desapropriadas para isso ${ }^{9}$.

Entretanto, cabe observar que, assim no caso de São Paulo, a legislação básica desta operação urbana, embora afirme de modo reiterado um compromisso com a questão da moradia no plano dos princípios e objetivos gerais, é notoriamente vaga quanto à especificação de obrigações do poder público nessa área. Enquanto no caso de outros aspectos do projeto, tais como

\footnotetext{
${ }^{9}$ Essa passagem foi extraída de reportagem publicada na página eletrônica da Companhia de Desenvolvimento Urbano da Região do Porto do Rio de Janeiro (CDURP). Mais Moradias no Porto, 19/10/2013. Disponível em: <http://www.portomaravilha.com.br/noticiasdetalhe/3956> Acesso em: 15/04/2018.
} 
obras viárias e equipamentos culturais, tal legislação apresenta elevado grau de especificação e detalhamento dos resultados pretendidos, prevendo, de modo sistemático, um conjunto determinado de intervenções, tais como a ampliação de vias, a construção de túneis e viadutos, a construção de museus, a restauração de edifícios e sítios arqueológicos, entre outros, no caso da habitação, as metas são deixadas em aberto, sendo expressas de modo genérico. Tais dispositivos legais não especificam aspectos como a quantidade de unidades habitacionais a serem providas, as formas de provisão a serem adotadas, as áreas de implantação de novos conjuntos habitacionais, a origem e o montante de recursos a serem direcionados a esta finalidade, os prazos de implementação de planos habitacionais, os órgãos diretamente responsáveis, e assim por diante. Embora seja um traço comum dessas duas operações urbanas, o nível de indeterminação das disposições normativas referentes à questão da moradia é ainda mais alto no caso do Porto Maravilha, em que a possibilidade de enforcement de compromissos relacionados à promoção do direito à moradia a partir da legislação específica do projeto é muito reduzida.

Na próxima seção, apresentamos um panorama de como veem se desenrolando os conflitos relacionados à questão habitacional nos dois casos, dando destaque à dinâmica das remoções ocorridas, às ameaças de remoção ainda presentes e às ações de provisão habitacional efetivamente implementadas ou em projeto.

\section{O hiato entre as promessas e a realidade da provisão habitacional nas operações} urbanas

\section{1. Água Espraiada}

A reconfiguração do cenário urbano da região onde hoje se situa a Avenida Jornalista Roberto Marinho (antiga Avenida Água Espraiada), bem como a escalada de ameaças de remoção incidindo sobre moradores de baixa renda em suas imediações, são processos que tiveram início muito antes do lançamento da OUCAE, em 2001. Desde a década de 1970, os interesses do setor imobiliário pela região da Marginal Pinheiros já estavam em nítida ascensão. Exemplo disso é a inauguração do Centro Empresarial São Paulo (1974) - empreendimento que sinalizava o surgimento de um novo polo empresarial na região. Esse processo se intensificou com a construção da Avenida Engenheiro Luís Carlos Berrini. Construída em meados da década de 1970, esta avenida transformou-se num dos principais polos de empreendimentos imobiliários de alto padrão na cidade nas décadas seguintes (FIX, 2001; FRÚGOLI JR., 2001). Alguns pesquisadores passaram inclusive a se referir à região da Marginal Pinheiros e da Berrini como o novo centro de São Paulo 
(ver FRÚGOLI JR, 2001; TOURINHO, 2006), o que evidencia a magnitude das transformações urbanísticas pelas quais essa região vem passando.

A construção da Avenida Jornalista Roberto Marinho figura como um elemento de importância central nesse processo de reconfiguração urbanística da região, tendo ampliado as fronteiras do circuito imobiliário local, assim como a escala dos conflitos relacionados à moradia. Em estudos da década de 1960, já se vislumbrava a implantação de uma avenida de grande porte no vale do Córrego Água Espraiada com o intuito de se criar uma nova conexão viária entre a Marginal Pinheiros, o Aeroporto de Congonhas e a Rodovia dos Imigrantes (principal conexão da capital com o litoral e o Porto de Santos), uma vez que a ligação existente (a Avenida dos Bandeirantes) encontrava-se saturada, com congestionamentos frequentes. A nova avenida foi pensada à época como parte do Anel Viário Metropolitano ${ }^{10}$ (Pequeno Anel Viário), com características de via expressa ${ }^{11}$. Já na década de 1970, iniciaram-se as desapropriações de terrenos às margens do córrego em vista à sua implantação. As obras, entretanto, demoraram para ter início - o que se deve, em grande medida, à deterioração das condições fiscais em todos os níveis de governo naquele período.

A viabilização da abertura desse eixo viário figura até os dias de hoje como uma das principais justificativas para a realização de uma operação urbana na região, e também como uma das principais fontes de conflitos relacionados à moradia no âmbito desse projeto, uma vez que o vale do Córrego Água Espraiada é uma área marcada pela presença expressiva de favelas e ocupações informais. A implantação do trecho existente da avenida (entre a Marginal Pinheiros e a Avenida Pedro Bueno, ver figura 3) ocasionou um conjunto numeroso de remoções ao longo das décadas de 1990 e 2000. Seu prolongamento até a Rodovia dos Imigrantes - intervenção cuja implementação passou a ser discutida em termos mais concretos no início da década de 2010, mas que permanece inconclusa até o momento atual - pode vir a ter como resultado o aumento

\footnotetext{
${ }^{10}$ Apesar de ter sido inicialmente pensada como parte do Pequeno Anel Viário, posteriormente essa abordagem foi revista: "Devido a grandes alterações na situação econômico nacional, a CMT - Câmara Metropolitana de Transportes optou por modificar a diretriz viária, transferindo o traçado do Anel viário para as avenidas Roque Petroni Jr, Vereador João de Luca e Cupecê" (EMURB,1996, p. 34).

${ }^{11}$ O projeto de abertura da então Avenida Água Espraiada, do início dos anos 1990, previa a conexão entre a Marginal Pinheiros e a Rodovia dos Imigrantes, totalizando cerca de 7km de via. No início da década de 1980, a então Secretaria de Vias Públicas (SVP) propôs sua implantação em duas etapas: "a primeira, entre a marginal e a Avenida Washington Luiz e a segunda, da Avenida Washington Luiz até a Rodovia dos Imigrantes, compreendendo também, a construção de uma ponte sobre o Rio Pinheiros, ligando os dois sentidos das marginais à nova via. (...) Posteriormente foi apresentado novo Projeto de Lei Municipal no 01-1098/1995, que prevê abertura e vias ao longo do córrego Água Espraiada, desde a Marginal Pinheiros até a Rodovia dos Imigrantes, (...) e extensão de 9,5 km” (EMURB, 1996, pp. 34-35).
} 
substancial do saldo de remoções decorrentes do projeto, conforme será exposto de modo mais detalhado à frente.

Figura 3. Operação Urbana Água Espraiada (OUCAE) - Trecho atual construído da Avenida Jornalista Roberto Marinho e favelas existentes ao longo do Córrego Água Espraiada. Produção

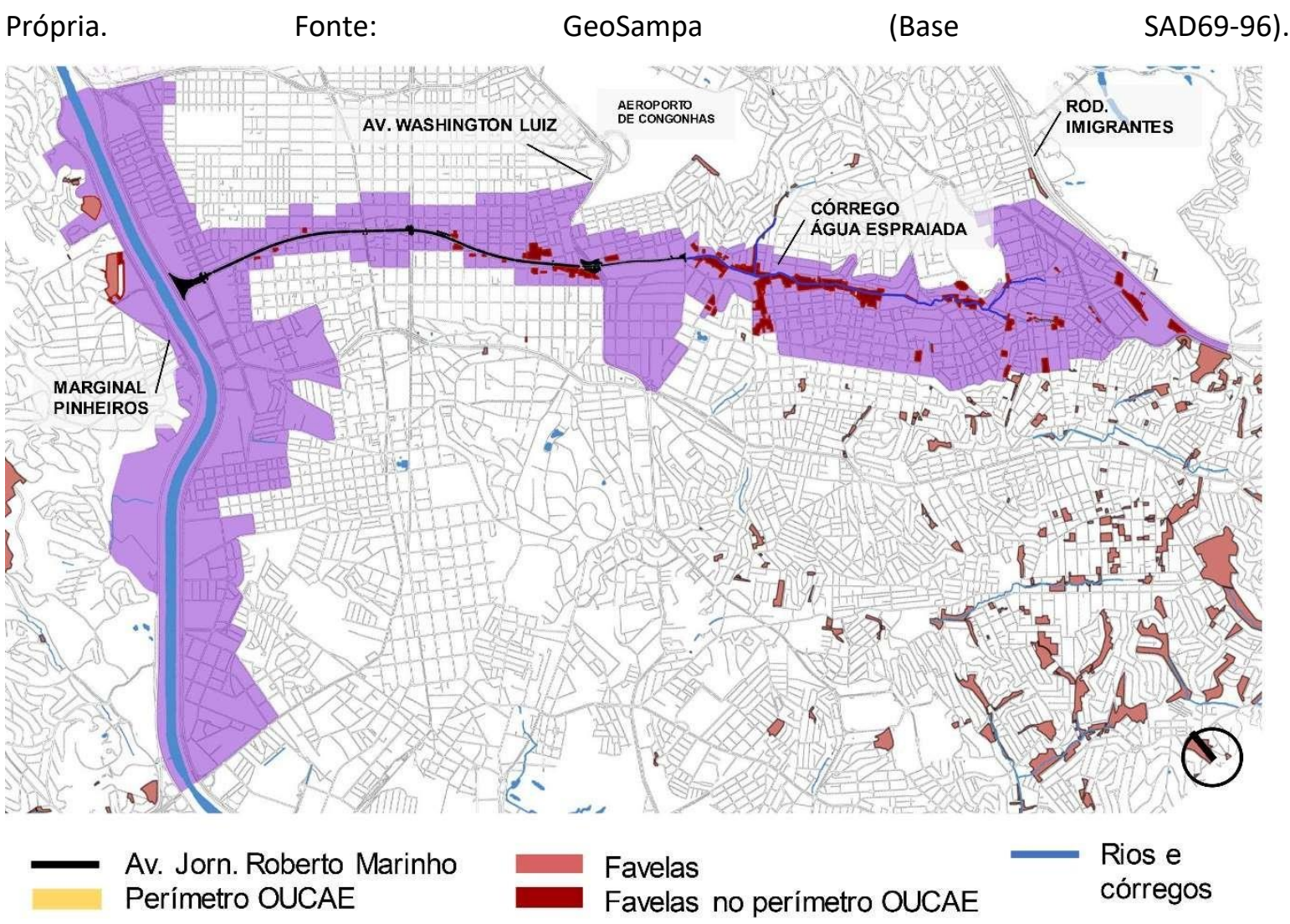


As obras para a abertura da Avenida Água Espraiada iniciaram-se efetivamente em 1994, na gestão de Paulo Maluf (1993-1997). Nessa época, existiam 68 núcleos de favelas e cerca de 50 mil moradores ao longo do córrego, que nasce perto do Aeroporto de Congonhas e deságua no Rio Pinheiros (FIX, 2001). Muitos desses núcleos surgiram nos mesmos terrenos desapropriados ainda na década de 1970, já que os projetos do Pequeno Anel Viário e da própria avenida demoraram muitos anos para ter início.

Figura 4. Vista aérea favelas na margem do córrego da Água Espraiada. Foto: FIX, 2001.

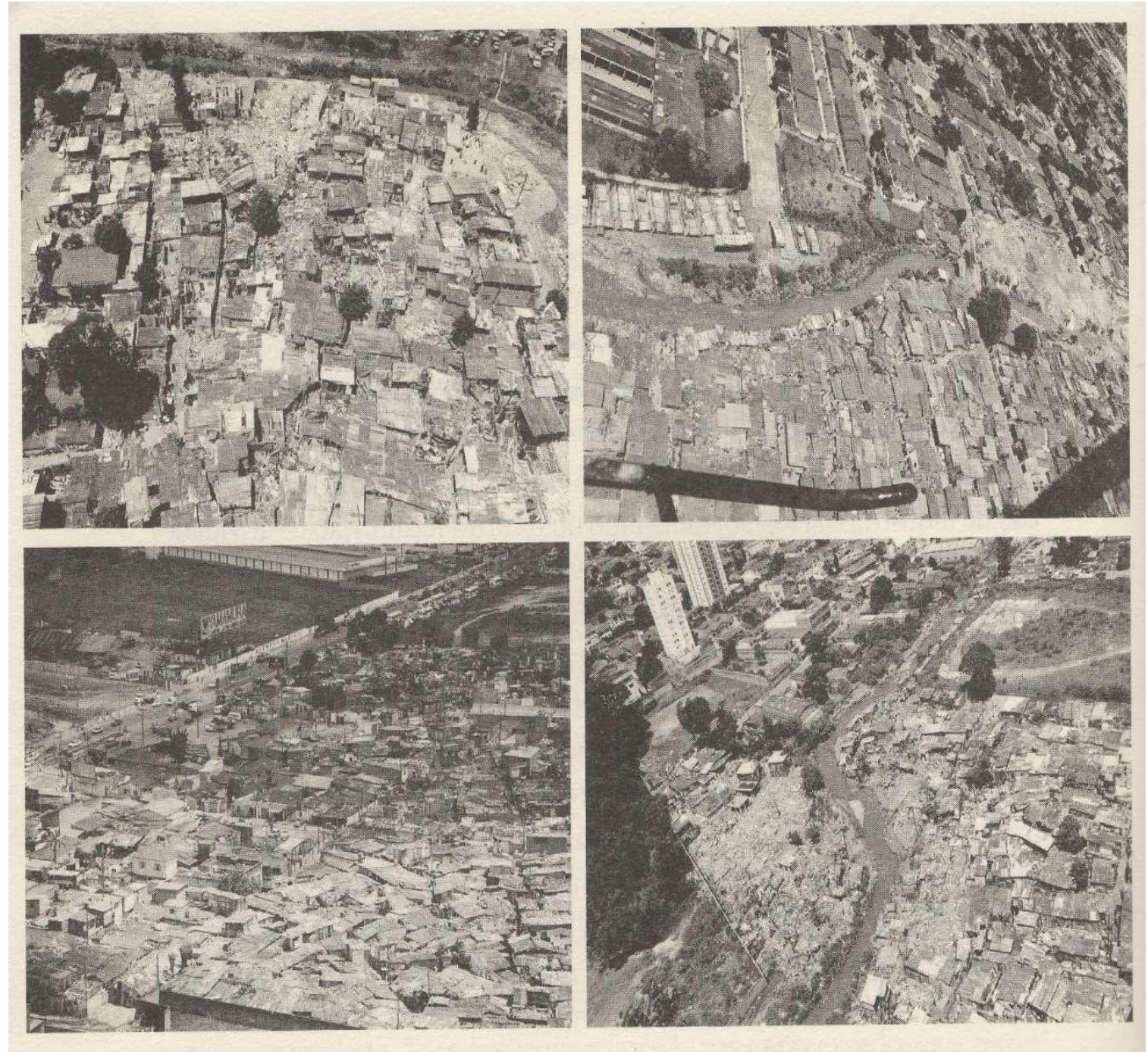


A partir do momento em que a implantação da avenida começou a se viabilizar, já em meados da década de 1990, o conflito fundiário veio à tona (ver figura 5). Apesar do fortalecimento dos movimentos populares de luta por moradia que se sucedeu ao processo de redemocratização, a remoção de favelas permanecia como um modus operandi consolidado na implantação de grandes projetos de infraestrutura urbana. Não fugindo à regra, a gestão de Paulo Maluf empenhou-se ativamente em remover favelas ao longo do Córrego Água Espraiada para abrir espaço para a construção da nova via expressa.

Figura 5. Início da construção da Avenida Água Espraiada, a partir da Avenida Eng. Luís Carlos Berrini, avançando sobre as favelas existentes ao longo do córrego. Fonte: FIX, 2001. 


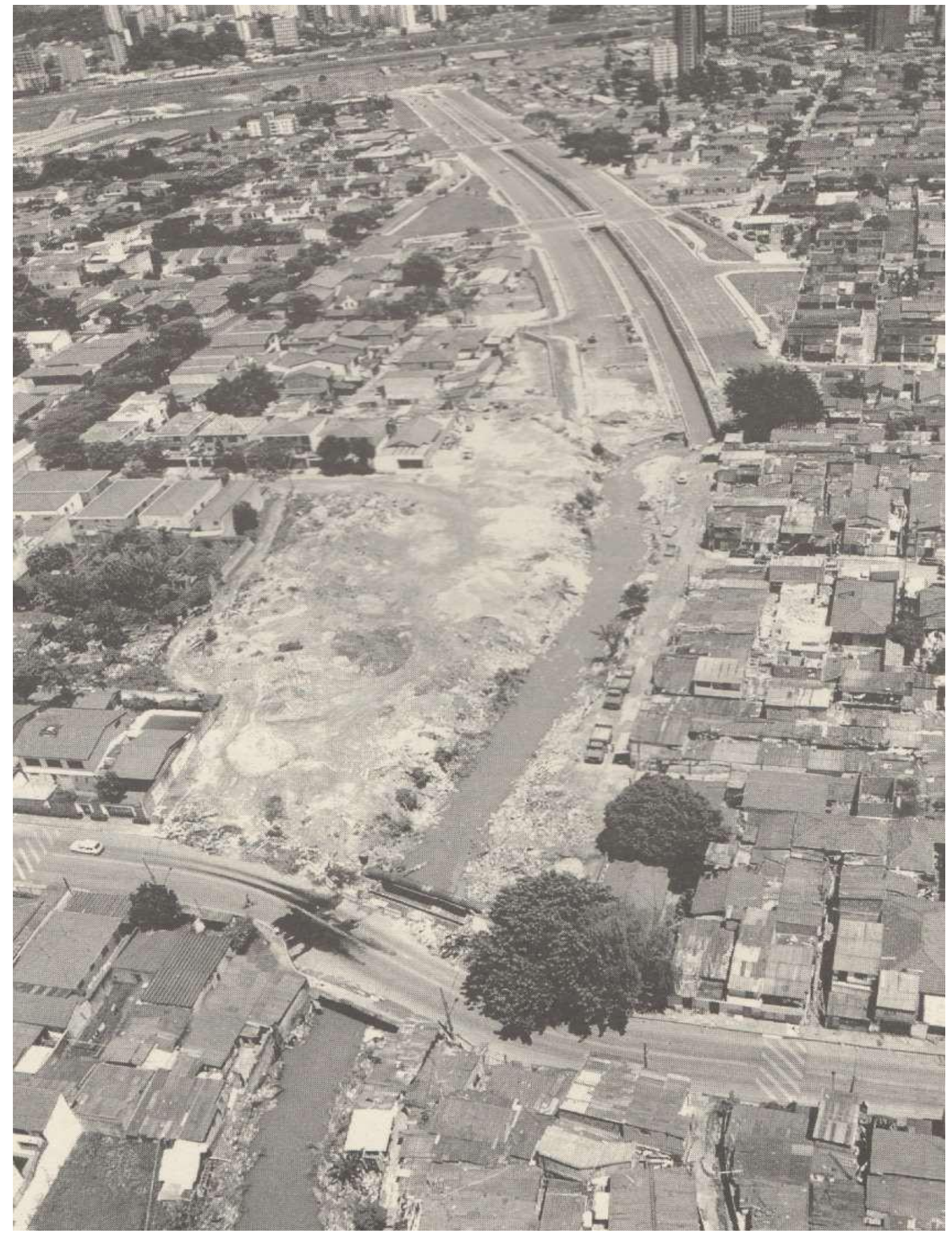

Conforme relata FIX (2001), o processo de remoção das favelas mais próximas à Marginal Pinheiros, onde se iniciou a obra, foi extremamente violento. Segundo a autora, os moradores eram cadastrados e os barracos marcados para demolição de forma abrupta, sem que fossem abertos 
canais efetivos de diálogo e negociação entre os moradores e a Prefeitura. Denúncias de moradores e da própria Defensoria Pública alegam que, para acelerar o processo de remoção, água e luz eram cortadas e frentes de trabalho eram abertas com a intenção de se isolar certos barracos, forçando a saída de moradores vizinhos. Além disso, havia forte discurso midiático ressaltando a potencialidade da região e reforçando a narrativa da necessidade de retirada das favelas do local, o que contribuía para respaldar as ações da Prefeitura e impulsionar o processo (ver figura 6).

Figura 6. Artigo publicado no Caderno de Imóveis da Folha de S. Paulo, 27 de agosto de 1995. Fonte: Acervo Folha de São Paulo

\section{FOUMADS. PAULO \\ imóveis \\ Domnga. 27 de agosto de I995 9.3 \\ Moradores resistem a abandonar região \\ Infra-estrutura do Brooklin proporciona uma boa qualidade de vida; nova avenida vai atravessar o terreno}
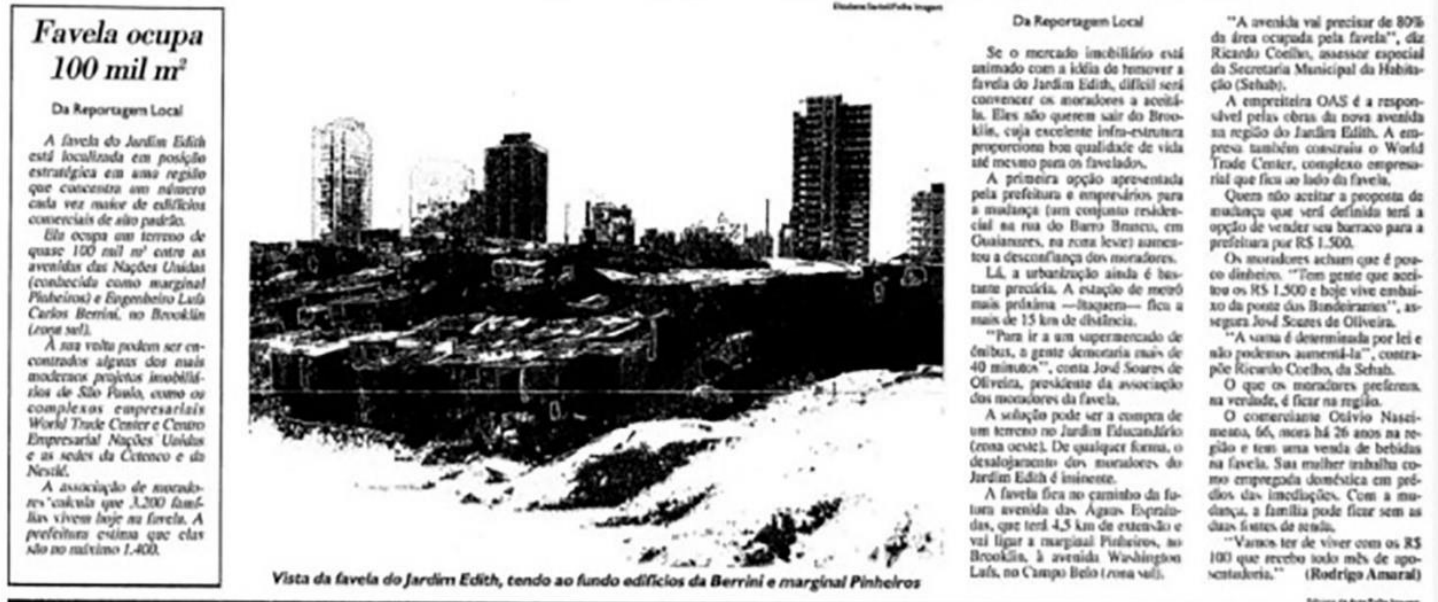

Segundo o estudo de FIX (2001), no momento do cadastro, os agentes da Prefeitura ofereciam três opções aos moradores: financiamento para a aquisição de uma unidade habitacional; indenização em dinheiro (o chamado "cheque despejo"); ou passagem de volta para a terra natal (grande parte dos moradores eram provenientes do Nordeste). Propunha-se o reassentamento de parte das famílias em um terreno da COHAB-SP (Companhia Metropolitana de Habitação de São Paulo) localizado em Cidade Tiradentes, na Zona Leste da cidade, a $50 \mathrm{~km}$ de distância. Aos que optaram pelo reassentamento, restava aguardar morando em alojamentos provisórios enquanto o apartamento não ficava pronto. Porém, segundo relatos de moradores afetados, a Prefeitura não disponibilizou a informação de que todos teriam direito à provisão habitacional definitiva, nem informou os prazos para a entrega dos apartamentos, o que gerava grande insegurança, estimulando a adesão às formas de atendimento mais imediatas, como a indenização, ainda que não representassem soluções de caráter definitivo para o problema habitacional. Segundo FIX 
(2001, p.41), menos de $5 \%$ da população optou por casas ou apartamentos nos conjuntos habitacionais. Em contraste com o que ocorria com as obras de HIS, as obras da via expressa, de custo bastante elevado, corriam a todo vapor, tendo sido o primeiro trecho da Avenida Água Espraiada oficialmente inaugurado em 10 de janeiro de $1996^{12}$.

A favela do Jardim Edith, com cerca de 12 mil moradores, foi a que teve maior visibilidade durante esse processo, apesar do fato de outros 40 mil moradores residentes em favelas da região terem sido removidos para a realização das obras do primeiro trecho da avenida. Ao fim, o Jardim Edith teve seu plano de reassentamento direcionado para um terreno localizado próximo à divisa com o Município de Taboão da Serra, a cerca de $15 \mathrm{~km}$ de distância da favela. Ainda que o terreno fosse distante e não comportasse a construção da totalidade de unidades habitacionais necessárias para o reassentamento de todos os moradores atingidos, a Prefeitura prosseguiu com a remoção deste núcleo, que era determinante para a viabilização da obra (FIX, 2001).

Figura 7. Remoção da favela do Jardim Edith: destroços dos barracos (1996) Fonte: FIX, 2001.

\footnotetext{
${ }^{12} \mathrm{O}$ trecho Avenida Água Espraiada inaugurado oficialmente estendia-se da Marginal Pinheiros até a Avenida Washington Luiz. O traçado atual com a conexão com a Avenida Pedro Bueno foi finalizado no final dos anos 2000/início dos anos 2010, com a pretensão de se iniciar as obras de continuidade da avenida até a Rodovia dos Imigrantes. No entanto, entre outubro de 1995 e a inauguração oficial desse primeiro trecho em janeiro de 1996, a Prefeitura abriu trechos da avenida. Em reportagem da Folha de São Paulo, informa-se a inauguração de um trecho de 1,2 km, entre a Avenida Santo Amaro e a rua Zacarias de Góis. Folha de são Paulo, Caderno Cotidiano, 27 de outubro de 1995.
} 


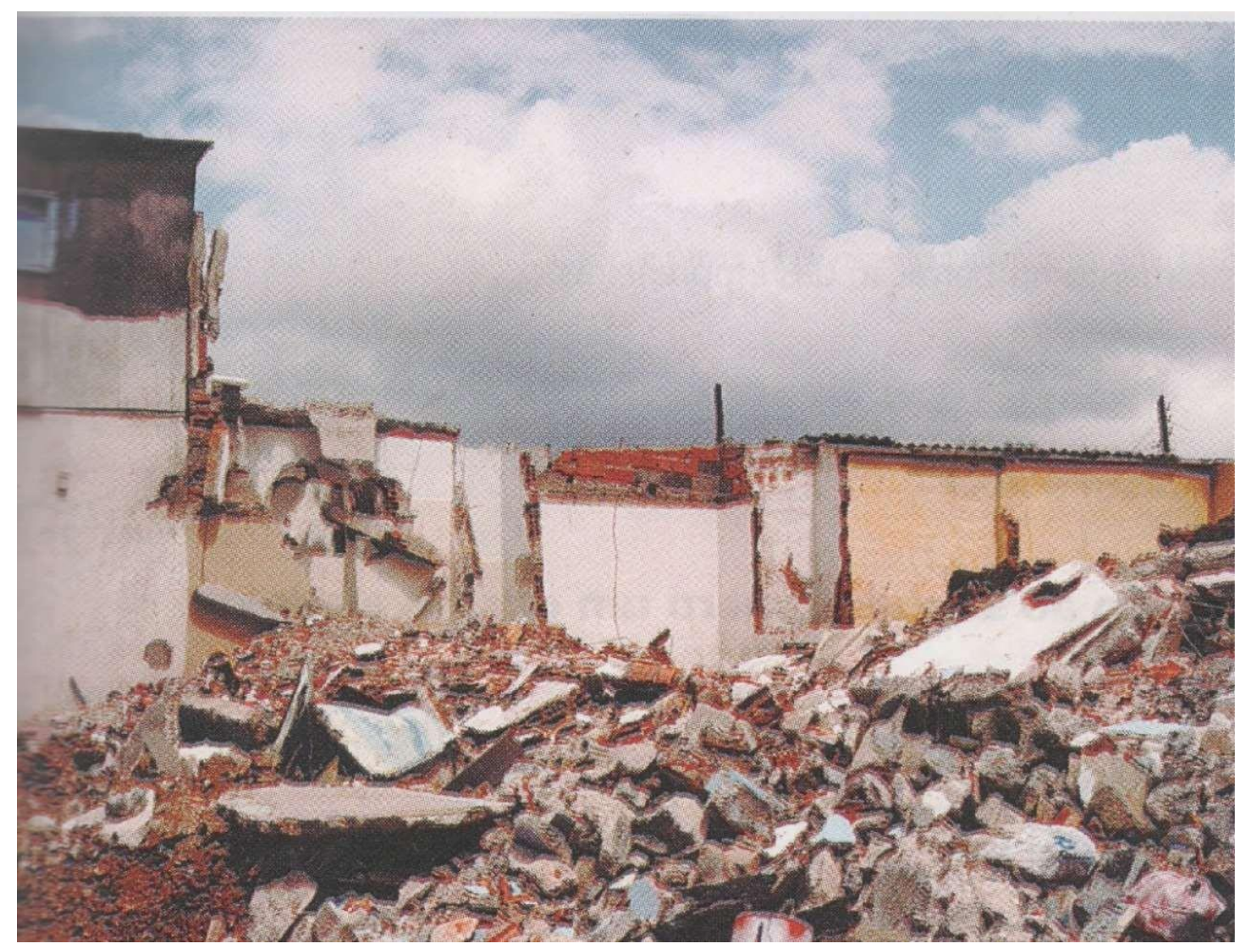


Revista de Direito da Cidade

vol. 12, no 1. ISSN 2317-7721

DOI: $10.12957 /$ rdc.2020.39495

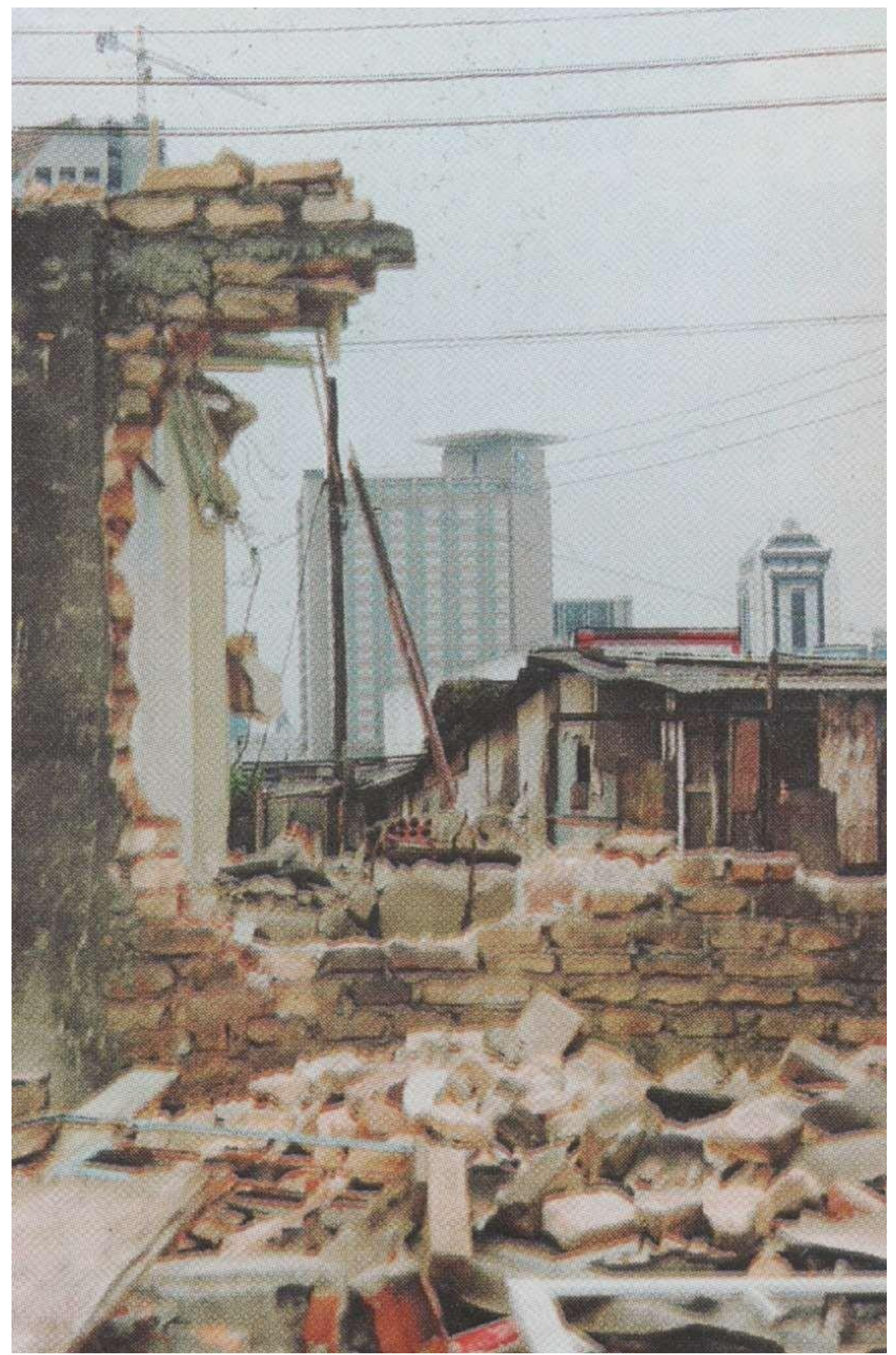


O processo de remoção do Jardim Edith prolongou-se por mais de uma década, sendo finalizado já num momento posterior à criação da OUCAE. Embora uma parte significativa de seus moradores já tivessem saído da região no período em que se iniciaram as obras da avenida, ainda na gestão de Paulo Maluf, alguns grupos resistiram às ameaças de remoção e se mobilizaram para reivindicar que o reassentamento ocorresse no local, pleiteando a construção de um conjunto habitacional na área onde se situava a favela (ver figura 8). À época das negociações de aprovação da OUCAE, os moradores demandaram a demarcação de uma zona especial de interesse social (ZEIS) no local, o que se concretizou com a aprovação do Plano Diretor Estratégico (PDE) de 2004.

Figura 8. Moradores resistem à remoção do restante da favela do Jardim Edith. Fonte: Revista Época, 2009 (foto: Marcelo Min).

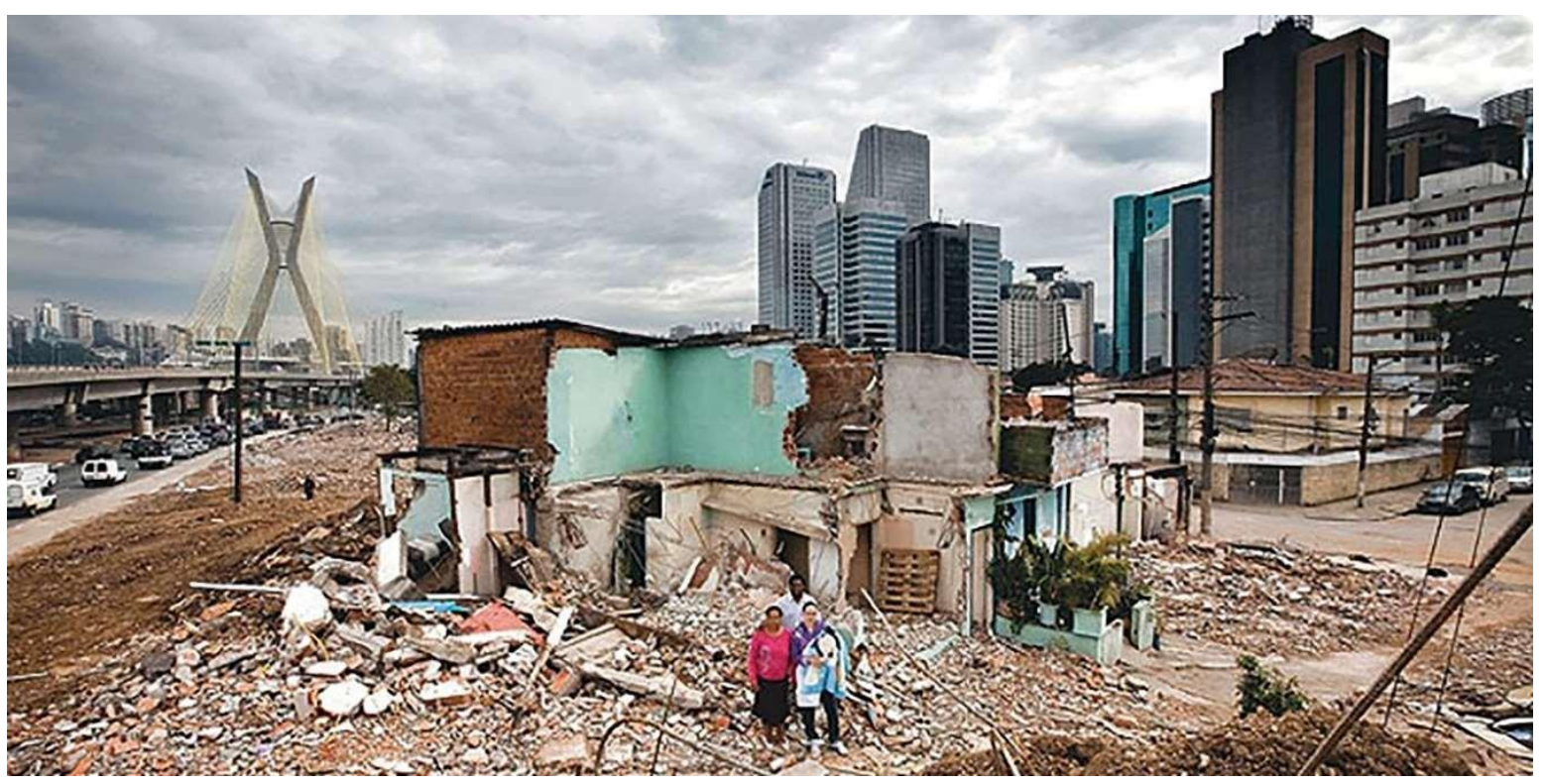

Após um longo período de mobilização dos moradores, marcado por negociações com governos de diferentes orientações políticas e por disputas judiciais, o pleito de construção de um conjunto habitacional no local foi atendido. Em 2013, passados doze anos da criação da OUCAE e quase vinte anos do início das remoções no local, a Prefeitura entregou o conjunto habitacional Jardim Edite ${ }^{13} \mathrm{I}$, primeiro conjunto habitacional construído com recursos da OUCAE. Com apenas 252 unidades habitacionais, foi construído onde parte da favela se localizava, no cruzamento da Avenida Jornalista Roberto Marinho com a Avenida Engenheiro Luís Carlos Berrini. Junto dele, foi

13 Curiosamente, os registros e os próprios moradores nomeiam a favela do Jardim Edith, com o final "th", enquanto que os conjuntos habitacionais, são nomeados pelo poder público de Jardim Edite, com "e" no final. Julgou-se, por motivos de preservação da memória e fins de pesquisa adotar tal distinção. Assim, durante todo o texto, os termos "Jardim Edith" se refere à favela e "Jardim Edite" se refere aos conjuntos habitacionais. 
entregue uma Unidade Básica de Saúde (UBS), uma creche com capacidade de atendimento de 160 crianças e um restaurante escola (construções em azul na figura 9). O conjunto Jardim Edite II, vizinho ao primeiro conjunto, foi entregue em agosto de 2017, com 68 unidades. É importante destacar a discrepância entre o número inicial de moradores removidos e os atendidos pelas unidades construídas, bem como a defasagem temporal entre a remoção e a efetiva provisão de uma alternativa habitacional de caráter definitivo.

Figura 9. Conjunto habitacional Jardim Edite I. MMBB Arquitetos \& H+F. Foto: Nelson Kon.

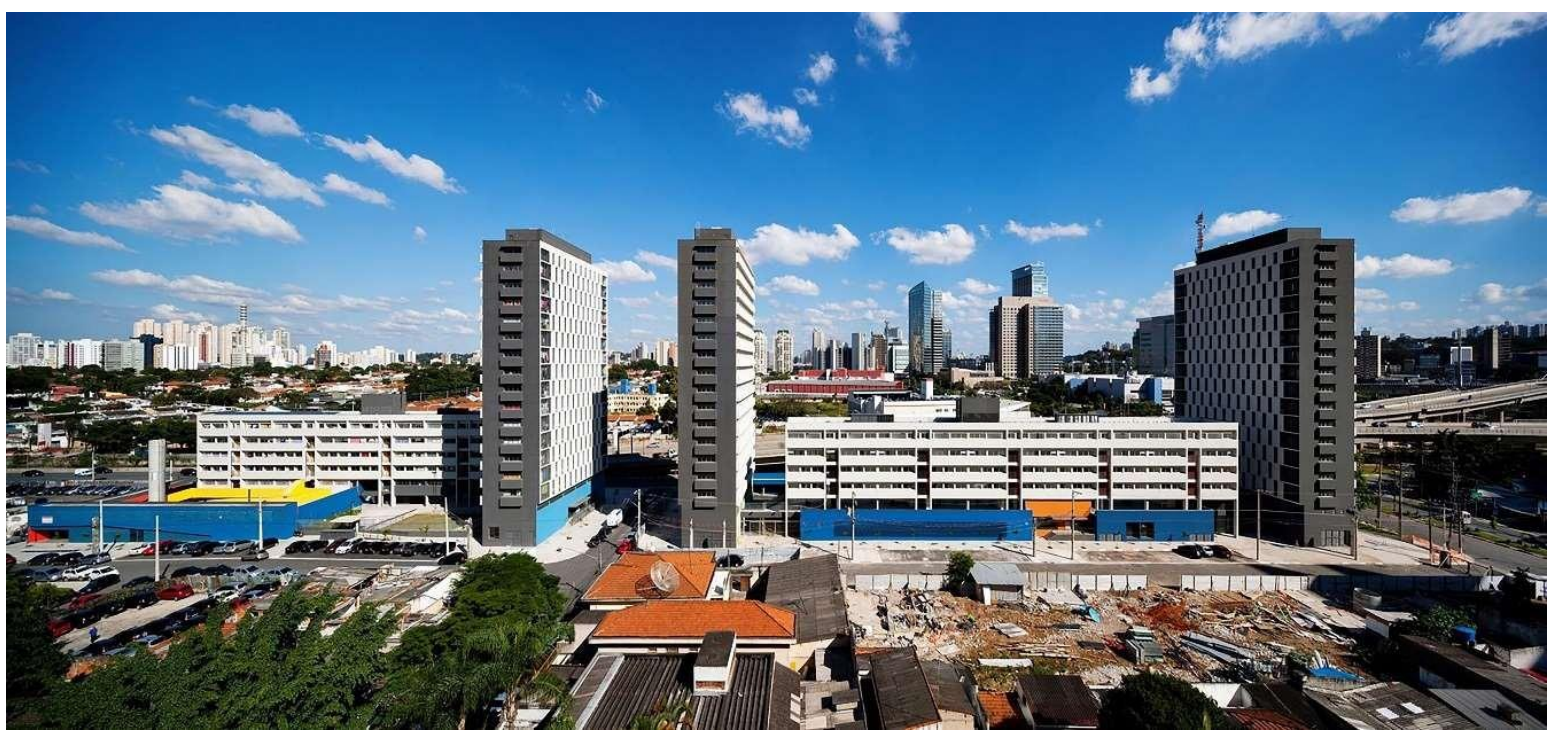

O caso da favela do Jardim Edith, que teve bastante visibilidade, é ilustrativo do tratamento conferido à questão da moradia no âmbito dessa operação urbana, contendo vários elementos de uma dinâmica que vem se repetindo ao longo do tempo. Destacam-se, nesse sentido, aspectos como a ausência de informações claras quanto às medidas de remoção previstas e às alternativas habitacionais a serem disponibilizadas, a discrepância entre o número de domicílios removidos e o de unidades produzidas, a defasagem cronológica entre a remoção de moradores e a entrega de unidades habitacionais, o reassentamento em locais distantes, a predominância de formas de atendimento de caráter transitório ou indenizatório e o preterimento sistemático de investimentos em habitação. Vale mencionar, nesse sentido, os apontamentos feitos em estudo do Observatório das Remoções a respeito dessa operação urbana:

Historicamente, as intervenções na região da OUCAE foram pautadas pelo argumento de que melhorias na mobilidade são de interesse público, coletivo e beneficiariam a cidade como um todo, o discurso oficial reitera essas ideias. Por exemplo, a criação e ampliação da Avenida Jornalista Roberto Marinho; seus projetos de continuidade para interligação com a 
rodovia dos Imigrantes e a criação de um parque linear, o Via Parque; além do mais recente projeto da linha Ouro 17 do Metrô (monotrilho), são exemplos dessa primazia. $\mathrm{O}$ argumento da universalidade dos benefícios de investimentos em mobilidade funciona, no caso, perversamente: como justificativa para embasar desapropriações e remoções forçadas de famílias e pessoas cuja permanência na região colide com os interesses dos vultosos investimentos privados de capital imobiliário e de infraestrutura, que veem na área possibilidade de expansão e retorno financeiro" (OBSERVATÓRIO DE REMOÇÕES, 2017, p. 42).

Após a criação da OUCAE, é possível notar algumas mudanças no tratamento dado à questão da moradia em comparação aos padrões vigentes no período anterior. Esse processo devese em parte à alternância política, com a eleição de governos mais comprometidos com a pauta da moradia em alguns períodos, mas em parte também à existência de dispositivos legais específicos das operações urbanas, que deram elementos adicionais para se pleitear judicialmente ações de provisão habitacional no âmbito desses projetos ${ }^{14}$. Ainda assim, os desequilíbrios entre as remoções e a provisão de HIS estiveram longe de se dissipar com o advento da OUCAE.

Ao longo do período de vigência da operação urbana, é possível identificar dois momentos distintos para fins analíticos. As principais diferenças entre eles dizem respeito ao foco territorial das intervenções, à sua escala e à magnitude dos conflitos socioespaciais desencadeados.

O que poderia ser chamado de primeiro período, compreendido entre o lançamento da operação e o final da década de 2000 , teve como foco principal a realização de obras de complementação viária, drenagem e qualificação paisagística ao longo do trecho já construído da Avenida Jornalista Roberto Marinho. A principal intervenção feita nesta etapa foi a Ponte Otávio Frias Filho (conhecida como "Ponte Estaiada"), construída no cruzamento da referida avenida com a Marginal Pinheiros. Além dela, foram construídos alguns viadutos de transposição no cruzamento da Avenida Jornalista Roberto Marinho com outras avenidas de grande porte (Santo Amaro, Vereador José Diniz e Rubem Berta), um conjunto de vias laterais para absorver o tráfego local, um sistema de galerias pluviais para a contenção de enchentes, dentre outras intervenções de menor porte. As remoções associadas a essas obras tiveram impactos de menor vulto, uma vez que a parcela mais expressiva já havia ocorrido no momento da construção do primeiro trecho da avenida. Assim, as demandas habitacionais a serem equacionadas pela operação urbana nesse período

\footnotetext{
${ }^{14}$ Como exemplo dessa tendência, pode-se mencionar uma ação civil pública movida pela Defensoria Pública em 2007 (Processo n ${ }^{\circ}$. 0138359-24.2007.8.26.0053 do TJSP) na qual se pleiteou a interrupção das remoções e a construção de um conjunto habitacional com recursos da OUCAE no Jardim Edith para o reassentamento de seus moradores. Essa ação judicial, cuja fundamentação jurídica valeu-se das disposições normativas gerais das operações urbanas e daquelas específicas da OUCAE, forçou a Prefeitura a negociar com os moradores e a se comprometer a implanter o referido conjunto habitacional.
} 
consistiam fundamentalmente em lidar com uma parcela do passivo deixado pela abertura da avenida no caso de moradores que seguiam mobilizados pelo atendimento definitivo no local e promover o reassentamento de moradores no caso de pequenas áreas de ocupação remanescentes cuja remoção se fazia necessária para a realização das obras mencionadas acima. Enquanto diversas das obras viárias previstas - inclusive algumas de proporções faraônicas, como a Ponte Estaiada foram entregues de modo razoavelmente rápido, não houve uma única unidade habitacional produzida com recursos da OUCAE ao longo de um lapso temporal de mais de uma década.

O que poderia ser caracterizado como um segundo momento da OUCAE, iniciando-se por volta do final da década de 2000 e se estendendo até hoje, apresenta como objetivo central o prolongamento do eixo viário da Avenida Jornalista Roberto Marinho até a Rodovia dos Imigrantes, incidindo fundamentalmente sobre a área que ainda não havia sido atingida de modo significativo pelas intervenções até o momento ${ }^{15}$. A proposta da Prefeitura abrangia inicialmente a construção de um túnel de aproximadamente $3 \mathrm{~km}$ de extensão conectando a avenida à Rodovia dos Imigrantes; de um parque linear ao longo do Córrego Água Espraiada; e de vias superficiais em paralelo ao parque, que ficaram conhecidas como Via Parque.

Esse conjunto de intervenções, por sua vez, implicava impactos socioespaciais bastante significativos, uma vez que envolvia a remoção de uma série de favelas localizadas ao longo desse trecho do córrego (ver figura 10). Apresentava também custos bastante elevados, estimando-se à época a necessidades de aproximadamente $\mathrm{R} \$ 3$ bilhões apenas para a construção do túnel.

Figura 10. Via Parque + HIS. Assentamentos irregulares e áreas previstas HIS Fonte: SP Urbanismo, 2016

\footnotetext{
${ }^{15}$ Outra frente de intervenções que entrou na agenda governamental nesse período foi o prolongamento da Avenida Chucri Zaidan (continuação da Berrini) até a Avenida João Dias. O intuito dessa frente de obras era abrir caminho para a ampliação do eixo de empreendimentos imobiliários de altíssimo padrão situados nas imediações do Rio Pinheiros. Além do prolongamento da avenida, o pacote de obras previsto incluiu também a construção de novas pontes sobre o Rio Pinheiros (o chamado Complexo do Real Parque), além de outras ações de menor custo. A frente de intervenções da Chucri Zaidan não teve impactos diretos sobre a questão da moradia, uma vez que não havia assentamentos populares no caminho das obras. Entretanto, tais intervenções têm impactos indiretos sobre a questão na moradia na OUCAE, uma vez que veem drenando recursos que poderiam ser destinados à construção de unidades habitacionais.
} 


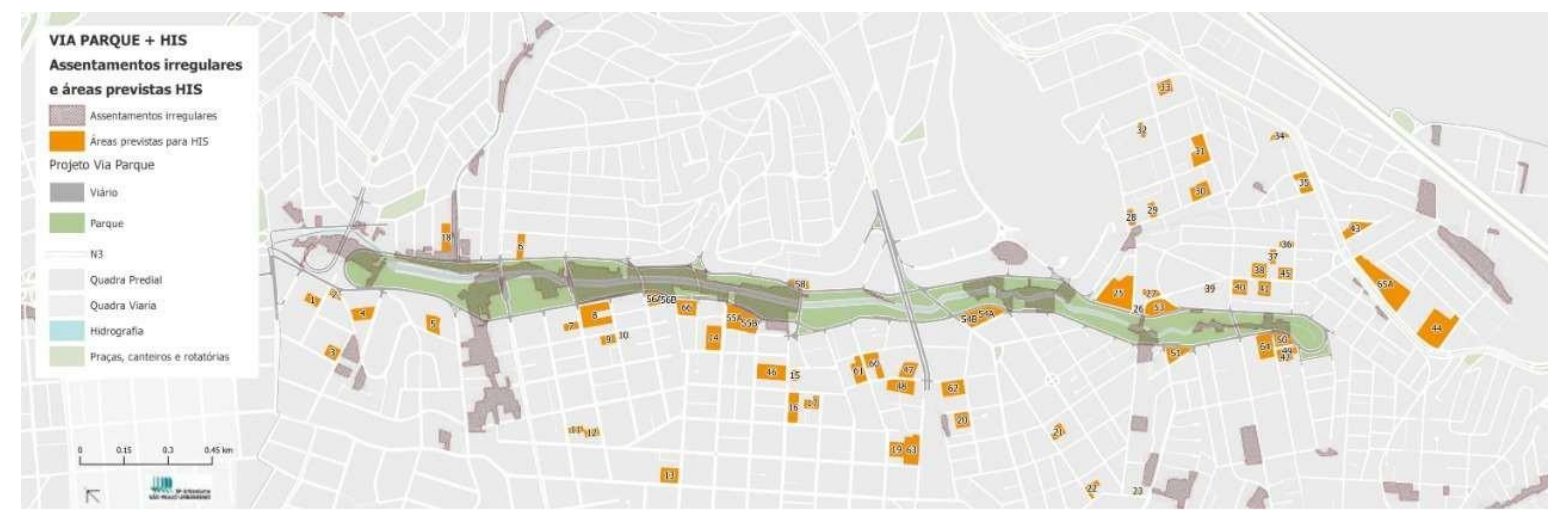

Essa rodada de intervenções ganhou impulso com os leilões de CEPACs ocorridos no ano de 2012. Arrecadaram-se aproximadamente $\mathrm{R} \$ 1,7$ bilhão nos leilões realizados naquele ano, parcela significativa do total de $\mathrm{R} \$ 2,9$ bilhões arrecadados no conjunto de leilões realizados desde a criação da OUCAE ${ }^{16}$. Supunha-se que os recursos arrecadados neste leilão garantiriam a viabilidade financeira dessa frente de intervenções - o que acabou não se concretizando. Contudo, chegou-se a licitar a realização deste pacote de obras ainda em 2012. O modelo de licitação adotado foi um tanto peculiar. Optou-se por dividir o objeto da licitação em quatro lotes, de modo que cada lote compreenderia a construção de um trecho de aproximadamente um quarto da extensão do túnel, da via parque e do parque linear, além da construção de 1000 unidades de HIS em cada trecho ${ }^{17}$. Cada lote ficou sob responsabilidade de um consórcio distinto, sendo todos eles liderados por grandes empreiteiras (ver figura 11).

Figura 11. Via Parque + HIS. Responsável pela execução das obras/Licitações. Fonte: SP Urbanismo, 2016

\footnotetext{
${ }^{16}$ Informações mais detalhadas sobre os leilões, a quantidade de CEPACs comercializados e os valores arrecadados podem ser obtidas na página eletrônica da PMSP, no endereço < https://www.prefeitura.sp.gov.br/cidade/secretarias/upload/desenvolvimento_urbano/sp_urbanismo/AGUA_ ESPRAIADA/2018/OUCAguaEspraiada30set18_HistoricoLeilao.pdf >

${ }^{17} \mathrm{O}$ edital previa também um quinto lote, cujo objeto era o pacote de intervenções relacionadas ao prolongamento da Avenida Chucri Zaidan. Este lote, entretanto, possui objeto bastante diferente dos outros quatro.
} 


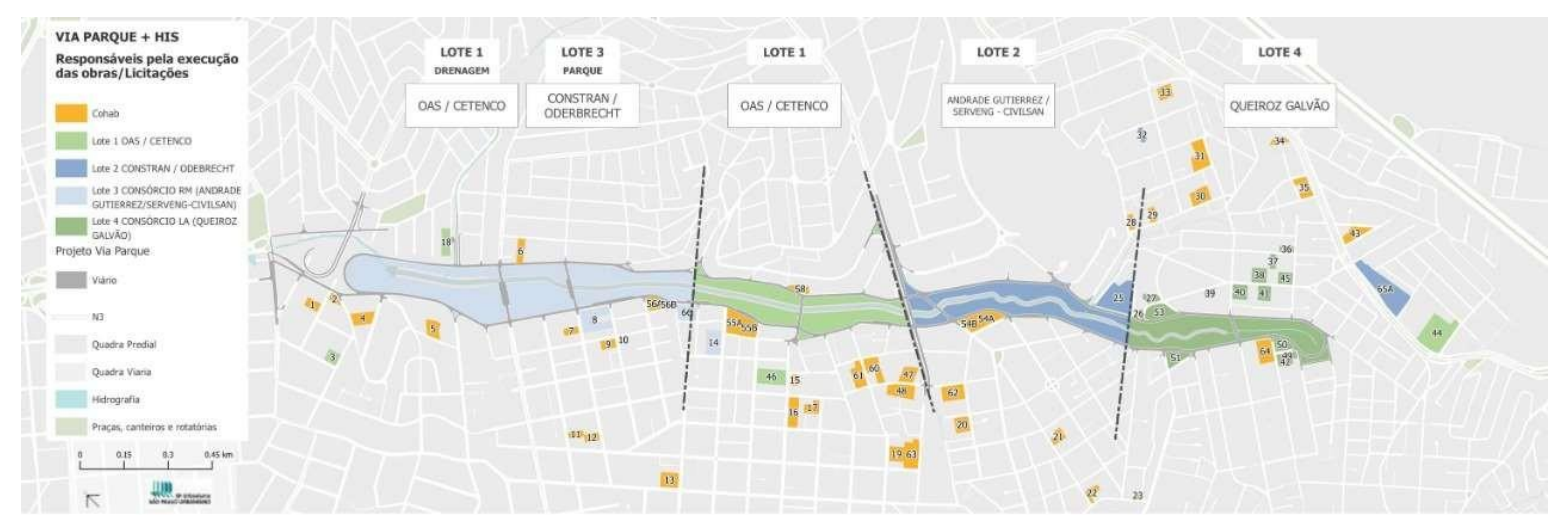

Apenas uma pequena parte desse ambicioso conjunto de intervenções foi de fato implementada ou encontra-se efetivamente em processo de implementação até o momento. Os rumos da OUCAE mudaram diante de fatores como o início da gestão de Fernando Haddad em 2013, a Operação Lava-Jato e, de modo mais amplo, a crise econômica iniciada em 2014, que teve forte impacto sobre o setor imobiliário em geral. Após a realização de consultas públicas ao Plano de Metas (2013-2016) da gestão de Fernando Haddad, a Prefeitura optou por desistir da construção do túnel naquele momento, já que se percebeu que esta intervenção não apenas consumiria grande parte dos recursos da operação urbana, como provavelmente ainda demandaria recursos adicionais, que dificilmente seriam angariados por meio de novos leilões de CEPAC num contexto de deterioração do cenário econômico e de perspectivas fracas para o setor imobiliário. Diante desse cenário, decidiu-se por alterar as prioridades da operação urbana, que passaram a ser a construção do parque linear e das vias adjacentes sem o túnel, o prolongamento da Avenida. Chucri Zaidan e, em tese, a construção de conjuntos de HIS.

A intenção da Prefeitura era aproveitar os contratos já estabelecidos para dar andamento às intervenções previstas, com exceção do túnel. Conforme mencionado anteriormente, as obras foram licitadas de maneira que cada lote incluiria a construção de 1000 unidades de HIS. Previa-se a construção de conjuntos habitacionais em terrenos localizados nas imediações do córrego, na maioria dos casos em áreas demarcadas como ZEIS. A Prefeitura encontrou dificuldades, entretanto, para negociar a execução parcial dos contratos diante da retirada do túnel de seu objeto. Os concessionários alegavam que a decisão de participar do processo licitatório devia-se fundamentalmente à construção túnel, de onde adviria a maior parte da remuneração prevista, de modo que essa mudança no escopo do contrato comprometeria seu equilíbrio econômico e financeiro. Com base nessa argumentação, as empreiteiras resistiram por muito tempo a aceitar a 
execução parcial dos contratos nos termos propostos pela Prefeitura ${ }^{18}$. Diante desse conjunto de fatores, as obras, as remoções e a construção dos conjuntos habitacionais previstos veem evoluindo em ritmo bastante lento.

Para além das dificuldades de execução dos contratos relativos a esse conjunto de intervenções, outro aspecto conflituoso no tocante à questão da moradia diz respeito à mensuração da demanda e ao dimensionamento das ações de atendimento habitacional. Há uma série de indicativos de que o montante de unidades de HIS previstas para construção, ainda que venha a ser entregue em sua totalidade, seja insuficiente para atender a toda a demanda de reassentamento gerada pela OUCAE. Desse modo, é possível supor que grande parte dessa população removida se deslocará para áreas mais periféricas, como assim o fizeram no início das obras da antiga Avenida Água Espraiada (FIX, 2001), já que não encontra acesso à moradia no entorno valorizado da operação, piorando suas condições de moradia e de vida e onerando ainda mais as áreas ambientalmente sensíveis da cidade.

Essa incongruência entre remoção e reassentamento pode ser constatada nesse conjunto de intervenções em particular e na OUCAE em geral quando se comparam os dados oficiais (ver figura 12) com os levantamentos extraoficiais estimados até hoje. Não fica clara a relação entre o total de famílias moradoras de favelas, as reassentadas e as removidas ${ }^{19}$. Além disso, não se específica com clareza quais são as favelas que passarão por processos de urbanização ou, se mapeadas para remoção, quando o processo ocorrerá. Estima-se que, até o momento, cerca de 11 mil famílias já sofreram remoção no perímetro da OUCAE, e que outras 8 mil estejam sob ameaça de remoção até o ano de 2020 (OBSERVATÓRIO DE REMOÇÕES, 2017), números esses muito superiores aos divulgados oficialmente (ver figura 12).

\footnotetext{
${ }^{18}$ Segundo relatos de entrevistados, as empreiteiras acabaram por ceder, aceitando a redução do objeto do contrato à construção do parque linear e das unidades de HIS, apenas no contexto posterior à deflagração da Operação Lava-Jato. Essa mudança de postura teria ocorrido porque, pressionadas pela impossibilidade de estabelecer novos contratos de obras públicas e pela escassez de atividades em geral provocada pela crise econômica, as empresas acabaram se vendo obrigadas a aceitar aquilo que estivesse a seu alcance naquele momento. Embora essas intervenções não gerassem taxas de retorno comparáveis ao que se esperava de um contrato abrangendo a construção do túnel, não deixavam de ser empreitadas lucrativas.

${ }^{19}$ Importante destacar que esse descompasso entre os processos de remoção e reassentamento na OUCAE vem fazendo com que parte dos recursos que poderiam ser investidos em soluções habitacionais definitivas acabem sendo consumidos pelo Bolsa-Aluguel - benefício concedido pelo munícipio de São Paulo às famílias de baixa renda removidas de suas casas enquanto não são atendidas definitivamente. Aproximadamente 3 mil famílias oriundas da Água Espraiada vivem em regime de habitação provisória, recebendo o Bolsa-Aluguel e configurando cerca de $10 \%$ das famílias que recebem esse benefício em todo o município (OBSERVATÓRIO DE REMOÇÕES, 2017). Os gastos com o Bolsa-Aluguel foram de cerca de 110 milhões de reais em 2018 (Departamento de Administração e Finanças/DAF - SEHAB. Gasto anual com programas de atendimento habitacional provisório).
} 
Figura 12. Gráfico HIS - Demandas e remoções. Fonte: SP Urbanismo, 2016

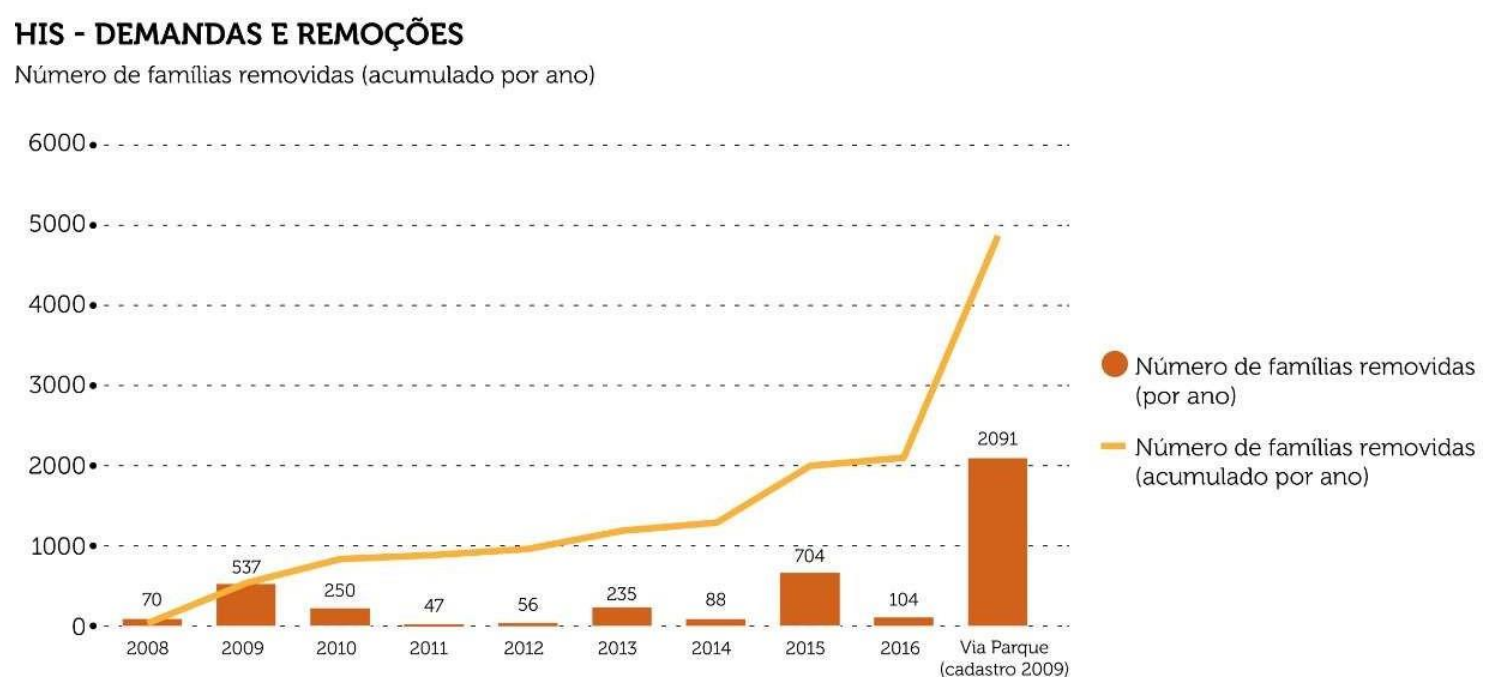

No perímetro da OUCAE, foram entregues, até o final de 2017, 778 unidades habitacionais ${ }^{20}$ das 9.297 previstas, o que representa menos de $10 \%$ do total (sendo que outros $58 \%$ das unidades ainda não foram contratadas, encontrando-se em processos de pendências contratuais, licitação, projeto ou a projetar - ver tabela 3). As unidades entregues se distribuem em sete conjuntos, nos setores Berrini, Brooklin e Jabaquara (com 320, 38 e 420 unidades cada, respectivamente - ver tabela 4)

\footnotetext{
${ }^{20}$ Das 778 unidades entregues, 710 estão em ZEIS, o que sugere que a reserva de terra para produção de HIS está sendo utilizada, em algum grau, na OUCAE. As maiores concentraç̃oes de perímetros de ZEIS estão nos setores Americanópolis e Jabaquara, que não por acaso, também concentram o maior número de favelas da operação. É nesses setores em que seriam construídas as demais unidades previstas.
} 
Tabela 3. Produção de HIS/Fases. Fonte: SP Urbanismo, 2016; PMSP, 2017.

\begin{tabular}{|l|l|}
\hline \multicolumn{1}{|l|}{ BANCO DE TERRAS } & \\
\hline TERRENOS & ÁREA $\left(\mathrm{m}^{2}\right)$ \\
\hline 73 & $204,6 \mathrm{mil}$ \\
\hline PRODUÇÃO HIS (até final de 2017) & No UH \\
\hline FASE & $\mathbf{7 7 8}$ \\
\hline Entregue & 1.998 \\
\hline Em obras & 1.112 \\
\hline Contratadas & 1.116 \\
\hline Contratos pendentes & 1.604 \\
\hline A licitar & 578 \\
\hline Em projeto & 2.111 \\
\hline A projetar & 9.297 UHs \\
\hline
\end{tabular}

Tabela 4. Produção Habitacional HIS na OUCAE. Fonte: PMSP 2017.

\begin{tabular}{|c|c|c|c|}
\hline CONJUNTOS & SETOR & & \\
\hline ENTREGUES & OUCAE & ANO & № UHs \\
\hline Corruíras & Jabaquara & 2013 & 244 \\
\hline HIS 03 & Jabaquara & 2015 & 74 \\
\hline HIS 18 & Jabaquara & 2016 & 102 \\
\hline HIS & Brooklin & 2013 & 19 \\
\hline \multicolumn{4}{|l|}{ Gutemberg } \\
\hline HIS Iguaçu & Brooklin & 2013 & 19 \\
\hline Jardim Edite I & Berrini & 2013 & 252 \\
\hline \multirow[t]{3}{*}{ Jardim Edite II } & Berrini & 2017 & 68 \\
\hline & & TOTAL & 778 \\
\hline & & & UHs \\
\hline
\end{tabular}

Da produção de HIS na OUCAE, destacam-se, além dos já citados conjuntos do Jardim Edite: o conjunto Corruíras (2013, ver figura 13), construído ao lado e para atender a demanda da antiga favela Minas Gerais (Jabaquara), com 244 unidades entregues (ver figura 12); a construção do conjunto Estevão Baião, com 300 unidades habitacionais no setor Brooklyn (ver figura 14), no entroncamento da Avenida Jornalista Roberto Marinho com a Avenida Washington Luís. O conjunto está em construção desde 2010, com previsão de entrega para 2019. 
Figura 13. Conjunto Habitacional Corruíras. Fonte: Boldarini Arquitetos Associados

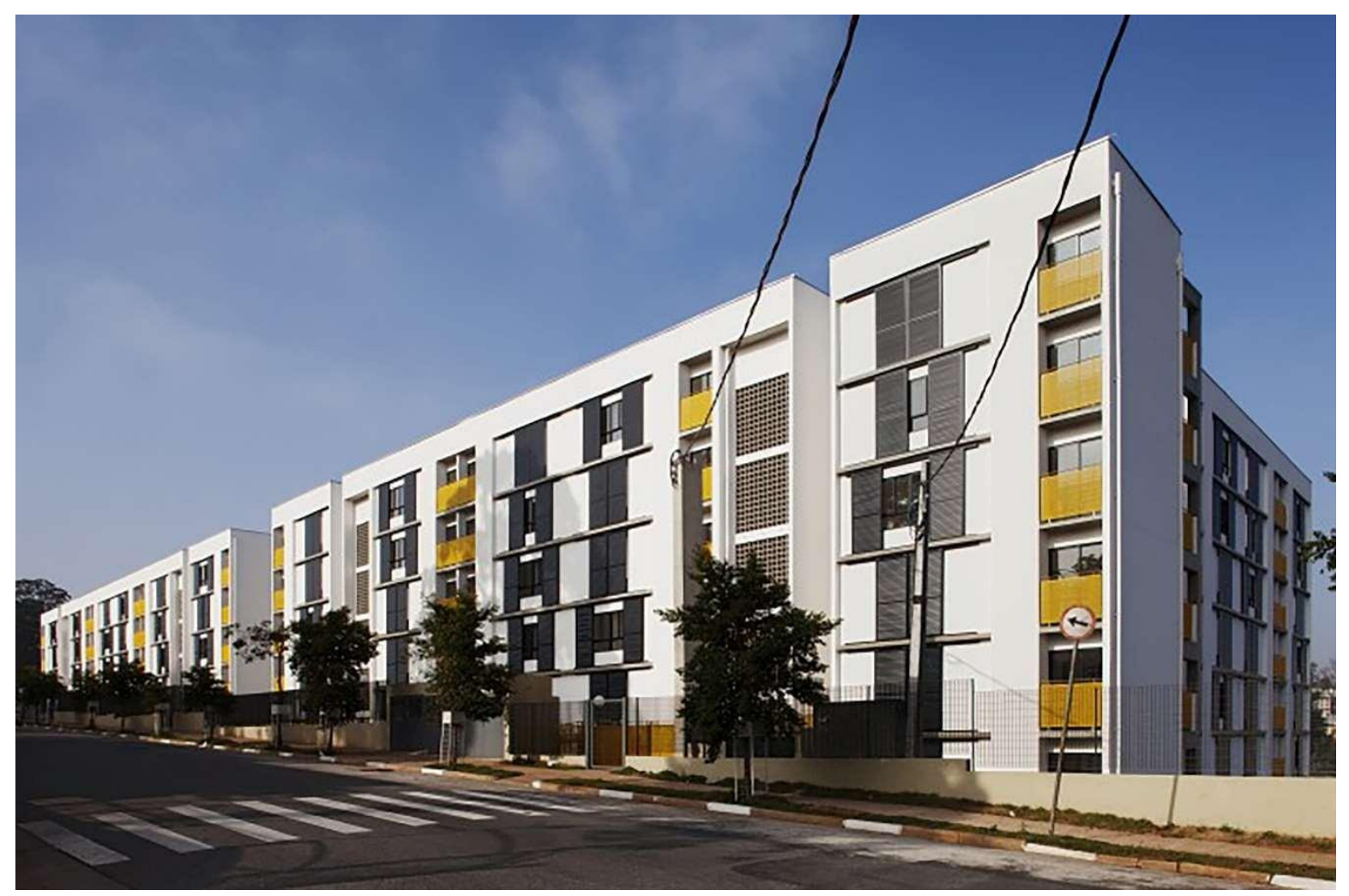

Figura 14. Conjunto Habitacional Estevão Baião, setor Brooklyn, OUCAE. Fonte: Joel Silva/Folhapress

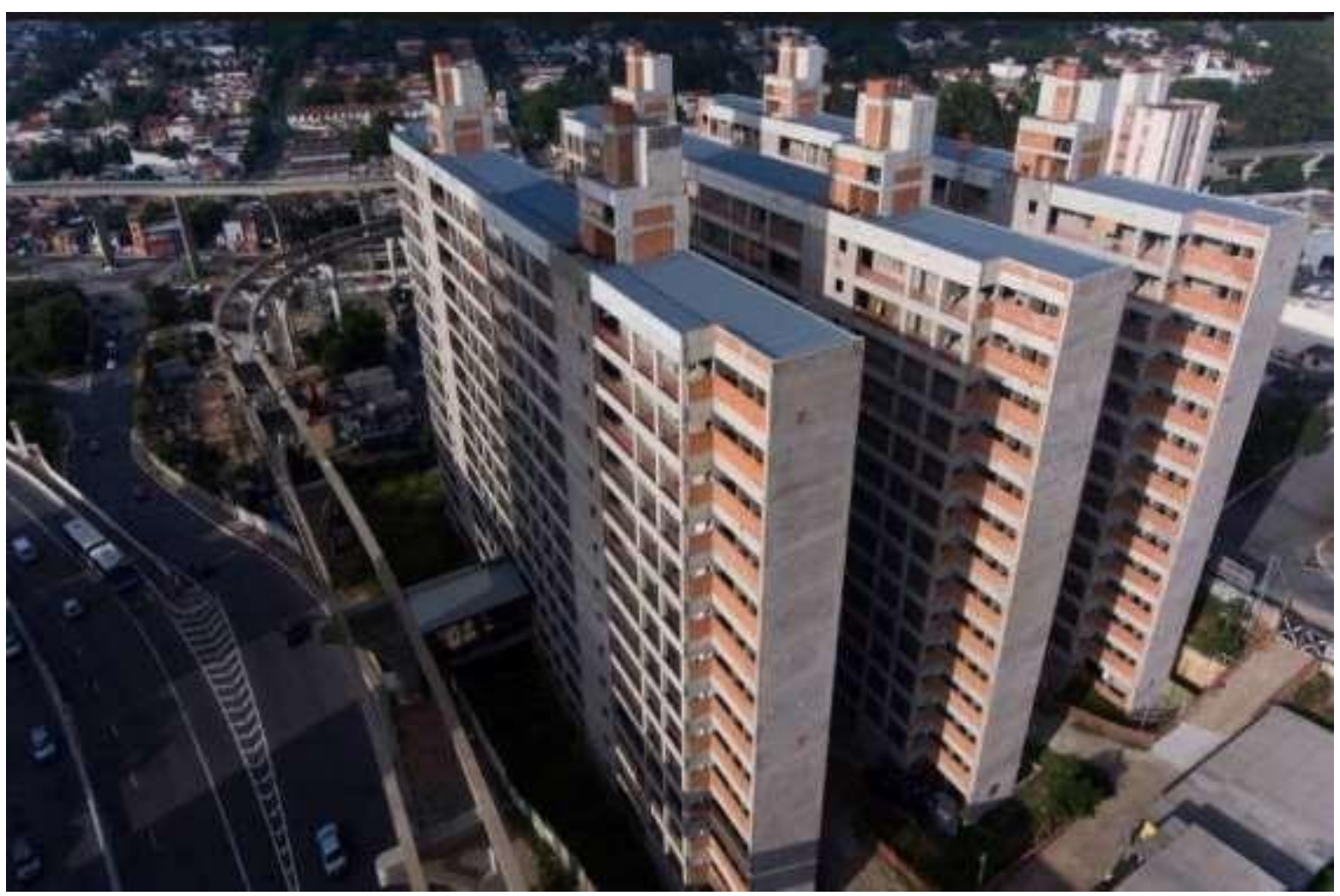




\subsection{Porto Maravilha}

Diferentemente do caso da OUCAE, as ações previstas no Projeto Porto Maravilha não provocaram uma situação de conflito direto com assentamentos populares previamente existentes no local. As principais ações previstas no projeto, tais como a demolição do Elevado da Perimetral, a construção de túneis, a implantação de linhas de veículo leve sobre trilhos (VLT), a construção de museus, a requalificação de redes de infraestrutura e do mobiliário urbano, a restauração do patrimônio histórico e arquitetônico e as demais ações de embelezamento urbano não desencadearam um montante significativo de desapropriações e remoções, de modo que os impactos deste projeto sobre a população local não tiveram a mesma magnitude que no caso de São Paulo.

No entanto, ainda que em menor escala, a implementação deste projeto também desencadeou um conjunto não negligenciável de conflitos relacionados à moradia (ver FAULHAUBER \& AZEVEDO, 2015; PEREIRA, 2016; WERNECK, 2016). Já no período anterior ao lançamento do Porto Maravilha, pode-se observar uma escalada de ações de reintegração de posse em ocupações situadas na região portuária. A região é marcada pela presença de um conjunto numeroso de terrenos e edificações, tanto públicos como privados, há muito tempo ociosos ou subutilizados. Diante desse cenário, muitos imóveis passaram a ser ocupados por movimentos de moradia, o que originou ocupações populares como o Quilombo das Guerreiras, a Flor do Asfalto, o Casarão Azul, a Zumbi dos Palmares, entre outras. Tais ocupações sempre estiveram, em alguma medida, sob ameaça de despejo. No entanto, enquanto prevalecia uma situação de relativo desinteresse em relação a essa área da cidade por parte do setor imobiliário, havia também menor pressão pela sua retirada. O cenário começou a mudar nos anos que precederam o lançamento do Projeto Porto Maravilha. Como prenúncio de um processo de "preparação do terreno" para o projeto de revitalização que vinha sendo idealizado para a região, pode-se observar, a partir da segunda metade dos anos 2000, uma escalada de ações de combate às ocupações até então existentes na zona portuária. Proliferaram nesse período ações de reintegração de posse visando à retomada de imóveis ocupados, bem como medidas de intimidação de seus moradores. Muitas dessas incursões ocorreram de modo violento, havendo inúmeros relatos de uso abusivo de força policial, falta de diálogo do Poder Público com os moradores, emprego deliberado de estratégias de deterioração das condições de vida no local e ausência de oferecimento de alternativas habitacionais adequadas a moradores sob risco de remoção.

Figura 15. Perímetro da OUC Porto Maravilha/Localização de Ocupações. Fonte: Silva, 2010 


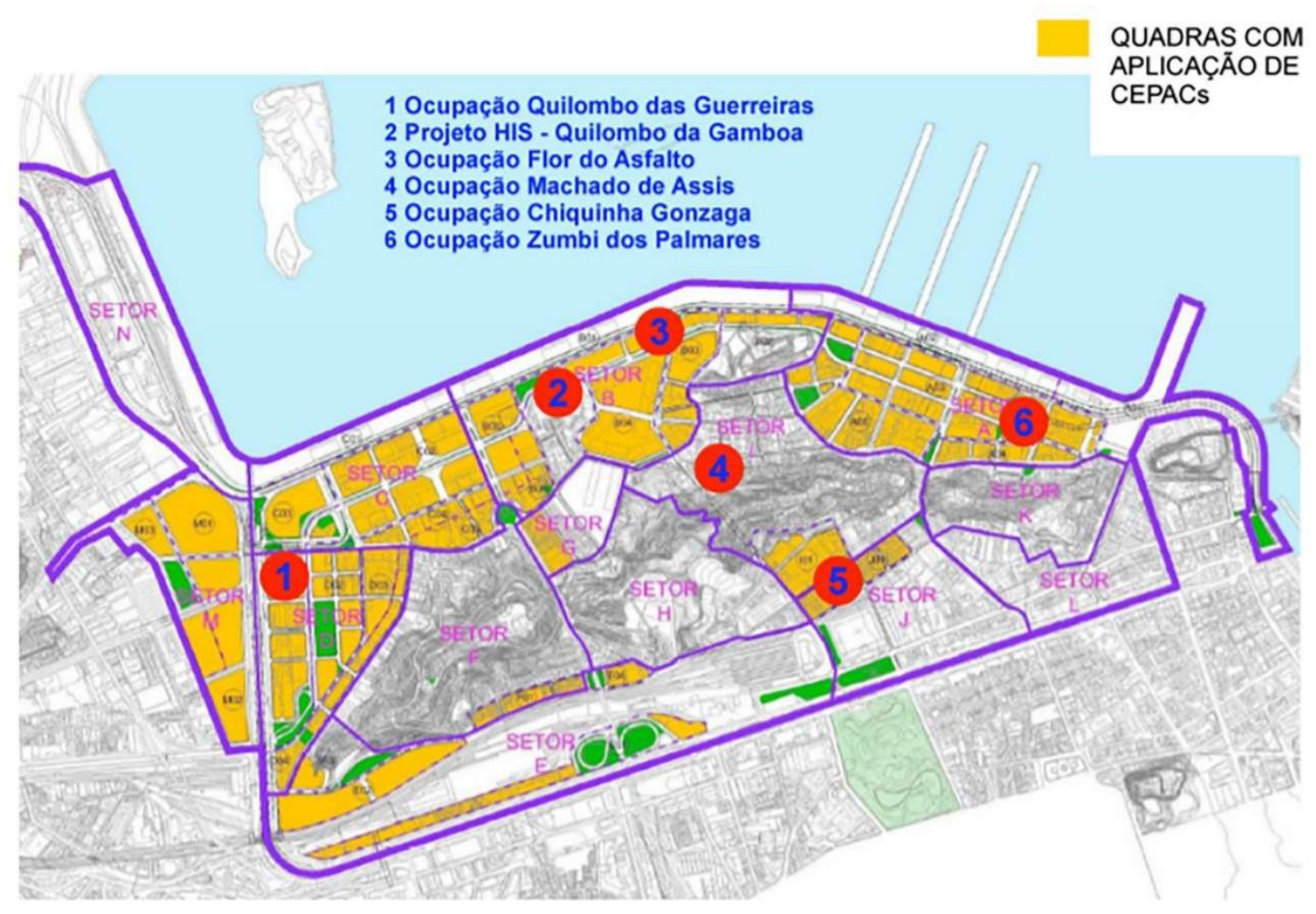

A dinâmica das investidas contra as ocupações existentes na região à época ocorreu de modo fragmentário e territorialmente disperso. Manifestando-se como episódios individuais, que afetavam grupos relativamente pequenos de moradores, essas remoções não alcançaram grande visibilidade de imediato, o que dificultou a organização de mobilizações e ações de resistência de maior envergadura. $O$ ímpeto remocionista dessa intervenção urbanística só começou a ganhar expressão mais clara alguns anos à frente, quando se anunciou um projeto de reurbanização do Morro da Providência. Nesse caso, a ameaça de remoção incidia sobre um conjunto de moradores numericamente expressivo e territorialmente concentrado, de modo que o conflito suscitado pelo processo em questão ganhou projeção muito maior que no caso dos episódios de remoção ocorridos anteriormente nas ocupações situadas na área plana da região portuária (ver FAULHAUBER \& AZEVEDO, 2015; OLIVEIRA, 2015). 
Figura 16. Morro da Previdência visto do mar. Foto: Bert Kohlgraf

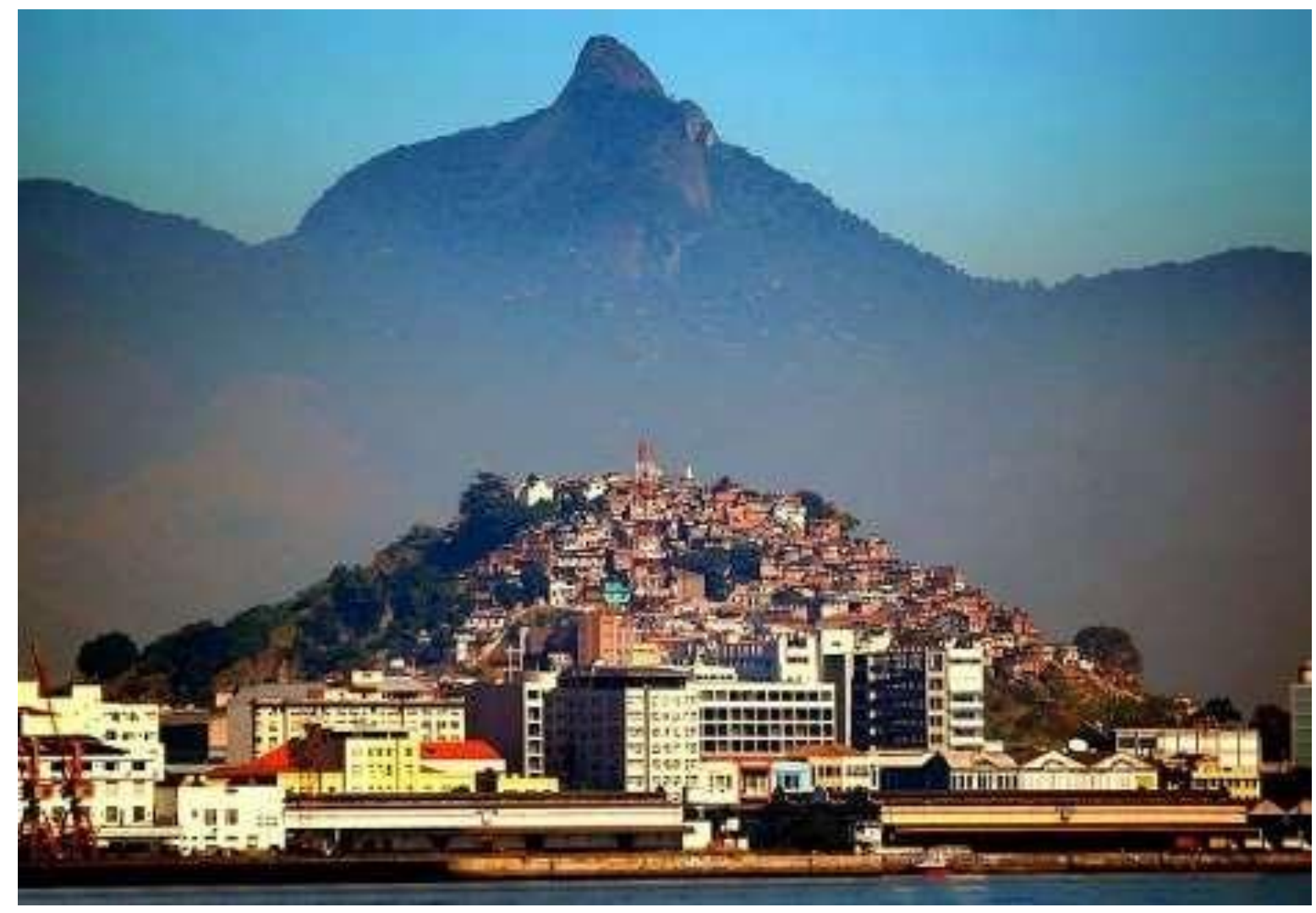

O Morro da Providência, localizado bem no centro da área de intervenção abrangida pelo Projeto Porto Maravilha, apresenta características socioespaciais razoavelmente heterogêneas, mesclando desde áreas de ocupação formal, habitadas por moradores de renda média, a áreas de ocupação irregular, marcadas pela presença de assentamentos de grande precariedade, habitadas por grupos de baixa renda e alta vulnerabilidade. Esse morro é dotado de forte expressão simbólica enquanto territorialidade popular na cidade do Rio de Janeiro, tendo ficado conhecido como a primeira favela do Brasil, e inclusive dado origem à associação do termo "favela" a um padrão específico de ocupação territorial. Sua ocupação em bases informais iniciou-se no final do século XIX, com o retorno dos soldados da Guerra de Canudos. Havia sido prometido aos soldados que, ao retornar da expedição, receberiam terrenos na então capital como parte da gratificação pelos serviços prestados à pátria. Diante da demora do governo em cumprir tal promessa, alguns soldados resolveram tomar uma "providência", tomando posse de terras situadas nesse morro para construir suas residências. Posteriormente, o povoamento do morro seguiu crescendo, tendo a área se afirmado como um dos locais prioritários de destino de grupos expulsos da cidade em virtude de ações de remoção de cortiços e outras intervenções associadas às políticas higienistas e planos de modernização do início do século XX. Tanto em termos morfológicos como simbólicos, o Morro da 
Providência e suas imediações carregam até os dias de hoje diversos dos traços que o fizeram ficar conhecido como a primeira favela do Brasil, caracterizando-se como uma área de ocupação eminentemente popular.

As normas e contratos públicos por meio dos quais se estruturou o conjunto principal de intervenções na região portuária deixaram o Morro da Providência inicialmente de fora de seu escopo. A elaboração de um projeto de intervenção específico para o morro, embora seja parte indissociável das transformações idealizadas para a região portuária como um todo, ocorreu em paralelo ao Projeto Porto Maravilha propriamente dito. O projeto de reurbanização do Morro da Providência foi proposto no âmbito do Programa Morar Carioca, uma política pública municipal de reurbanização de favelas que estava em andamento há mais tempo, e que se direcionava também a outras comunidades. Diferentemente das ações enquadradas como objeto da operação urbana, que ficaram sob responsabilidade da Companhia de Desenvolvimento Urbano da Região do Porto do Rio de Janeiro (CDURP), as ações do Morar Carioca foram atribuídas à então Secretaria Municipal de Habitação (SMH). Além disso, as ações do Morar Carioca na Providência não recebiam recursos oriundos da venda de CEPACs. O programa seria custeado com recursos orçamentários, a partir de uma cooperação entre a Prefeitura e o Governo Federal, que destinaria recursos por meio do Programa de Aceleração do Crescimento (PAC) - Urbanização de Favelas.

O projeto de reurbanização, nos moldes como concebido e apresentado, envolvia um conjunto abrangente de intervenções sobre o morro. A mobilidade era um de seus eixos principais, abrangendo ações como a implantação de um teleférico e de um plano inclinado, que fariam a conexão da Estação Central do Brasil e do Bairro da Gamboa com o topo do morro; o alargamento de logradouros; e a implantação de uma via para o trânsito de motocicletas, de modo a se facilitar a circulação de veículos motorizados em áreas de difícil acesso. Outro eixo relevante do projeto era a criação ou valorização de espaços com potencial turístico. O projeto abrangia a abertura de praças e largos, a implantação de novos mirantes e a restauração de edificações e sítios arqueológicos com notável relevância histórica e potencial apelo turístico. Por fim, o projeto previa também a retirada de casas em situação de risco e a construção de alguns conjuntos habitacionais nas imediações do morro, em local próximo à Estação Central do Brasil.

O projeto de reurbanização foi anunciado pouco depois da instalação de uma Unidade de Polícia Pacificadora (UPP) no local. Segundo relatos de moradores, a percepção inicial da comunidade em relação ao projeto foi positiva. O cenário começou a se alterar quando a Prefeitura deu início às remoções que julgava necessárias para sua implementação. Segundo estimativas da Comissão de Moradores, se a Prefeitura tivesse logrado remover todos os imóveis que havia 
demarcado com essa finalidade, um contingente próximo à metade da população do morro teria sido retirado do local ${ }^{21}$. Além do fato de o volume de remoções almejado pela Prefeitura ser bastante impactante, as alternativas efetivamente oferecidas foram revelando um quadro bem distinto da expectativa de atendimento integral do conjunto de removidos com soluções adequadas e definitivas em áreas próximas, o que desencadeou ações de resistência por parte de grupos de moradores e entidades da sociedade civil que atuavam no local.

O conflito entre grupos de moradores sob ameaça de remoção e a Prefeitura culminou com a propositura de uma ação civil pública pela Defensoria Públicaa ${ }^{22}$, na qual se pleiteou a interrupção

\footnotetext{
${ }^{21}$ Essa estimativa consta no documento intutulado "Carta Aberta à População do Rio de Janeiro", elaborado pela Comissão de Moradores do Morro da Providência em 2012 com o intuito de dar maior visibilidade aos impactos das obras de reurbanização do morro. $\mathrm{O}$ documento está disponível em https://forumcomunitariodoporto.wordpress.com/2012/09/12/carta-aberta-a-populacao-do-rio-de-janeiro/ Acesso em 16/01/2019.

${ }^{22}$ Ver Processo $n^{\circ}$. 0115786-70.2012.8.19.0001 do TJRJ.
}

\section{Referências Bibliográficas}

ALFONSÍN, Betânia. A Política Urbana em disputa: desafios para a efetividade de novos instrumentos em uma perspectiva analítica de Direito Urbanístico Comparado (Brasil, Colômbia e Espanha). Tese (Doutorado) - Instituto de Planejamento Urbano e Regional, Universidade Federal do Rio de Janeiro, Rio de Janeiro, 2008.

BALBIM, Renato; CAMPAGNE, Larissa. Operações urbanas e transformação do território das cidades: o caso de São Paulo. Boletim Regional Urbano e Ambiental, v. 6, p. 61-73, 2011.

EMURB. Estudo de Impacto Ambiental do Projeto da Via Expressa e Operação Urbana Água Espraiada. Volume I. São Paulo, fev/1996.

FAULHABER, Lucas; AZEVEDO, Lena. SMH 2016: remoções no Rio de Janeiro Olímpico. Rio de Janeiro: Mórula, 2015.

FERREIRA, Paulo Emílio Buarque. O Filé e a Sobra. As favelas no caminho do capital imobiliário. Tese (Doutorado em Arquitetura e Urbanismo) - Faculdade de Arquitetura e Urbanismo, Universidade de São Paulo. São Paulo, 2017.

FIX, Mariana. A fórmula mágica da parceria público-privada: operações urbanas em São Paulo. Cadernos de Urbanismo, n.3. Rio de Janeiro: Prefeitura Municipal do Rio de Janeiro, 2000.

Parceiros da exclusão. Duas histórias da construção de uma 'nova cidade' em São Paulo: Faria Lima e Água Espraiada. São Paulo: Boitempo, 2001.

FOLHA DE SÃO PAULO. CADERNO COTIDIANO. Maluf inaugura nova avenida na Zona Sul. São Paulo, 27/10/1995. Caderno Cotidiano. Disponível em: <https://www1.folha.uol.com.br/fsp/1995/10/27/cotidiano/53.html>. Acesso em: 08 jan. 2019.

FRÚGOLI JR., Heitor. A questão da centralidade em São Paulo: o papel das associações de caráter empresarial. Revista de Sociologia Política, v. 16, p. 51-66, jun 2001.

G1 GLOBO (São Paulo). Inauguração de ponte em SP tem protesto por moradia e ciclovias. 2008. Disponível em: <http://g1.globo.com/Noticias/SaoPaulo/0,,MUL465374-5605,00INAUGURACAO+DE+PONTE+EM+SP+TEM+PROTESTO+POR+MORADIA+E+CICLOVIAS.html> . Acesso em: 21/06/2017. 
KLINK, Jeroen; DENALDI, Rosana. On urban reform, rights and planning challenges in the Brazilian metropolis. Planning Theory, v. 15, p. 402-417, 2016.

MONTANDON, Daniel. T. Operações urbanas em São Paulo: da negociação financeira ao compartilhamento equitativo de custos e benefícios. Dissertação (Mestrado - Faculdade de Arquitetura e Urbanismo, Universidade de São Paulo, São Paulo, 2009.

LOGAN, John; MOLOTCH, Harvey. Urban Fortunes: The Political Economy of Place. Berkeley, Los Angeles e Londres: University of California Press, 1987.

PEREIRA, Alvaro L. S. Intervenções em centros urbanos e conflitos distributivos: modelos regulatórios, circuitos de valorização e estratégias discursivas. Tese (Doutorado) - Faculdade de Direito, Universidade de São Paulo, São Paulo, 2016.

OBSERVATÓRIO DE REMOÇÕES (2017). Relatório Final de Projeto: 2015-2017. São Paulo: FAUUSP, 2018.

OLIVEIRA, Nelma G. O poder dos jogos e os jogos de poder: os interesses em campo na produção de uma cidade para o espetáculo esportivo. Rio de Janeiro: Editora UFRJ/ANPUR, 2015.

RIO DE JANEIRO. COMPANHIA DE DESENVOLVIMENTO URBANO DA REGIÃO DO PORTO DO RIO DE JANEIRO (2013). Mais Moradias no Porto. 19/10/2013. Disponível em: <http://www.portomaravilha.com.br/noticiasdetalhe/3956> Acesso em: 15/04/2018.

RIO DE JANEIRO. MUNICÍPIO DO RIO DE JANEIRO (2017) Prospecto de Registro da Operação Urbana Consorciada da Região do Porto do Rio de Janeiro. Disponível em:

$<\mathrm{http} / / / \mathrm{www}$.portomaravilha.com.br/conteudo/canal_investidor/prospecto/prospecto-sem-marcas-de-revisao9-e-10-termos-aditivos.pdf> Acesso em 10/05/2018

ROLNIK, Raquel. Democracia no fio da navalha: limites e possibilidades para a implementação de uma agenda de reforma urbana no Brasil. Revista Brasileira de Estudos Urbanos e Regionais, v. 11, p. 31-50, 2009.

SÁNCHEZ, Fernanda; BROUDEHOUX, Anne-Marie. Mega-events and urban regeneration in Rio de Janeiro: planning in a state of emergency. International Journal of Urban Sustainable Development, v. 5(2), p. 132$153,2013$.

SANDRONI, Paulo. Plusvalías urbanas en Brasil: creación, recuperación y apropiación en la ciudad de Sao Paulo. In: SMOLKA, Martin; FURTADO, Fernanda (eds.). Recuperación de plusvalías en América Latina. Santiago: Instituto de Postgrado e Investigación; Pontificia Universidad Católica de Chile, 2001.

SÃO PAULO. Caderno Operação Urbana Consorciada Água Espraiada. São Paulo: Prefeitura Municipal de São $\quad$ Paulo, 2016.2 Disponível em:

$<$ https://www.prefeitura.sp.gov.br/cidade/secretarias/upload/desenvolvimento_urbano/sp_urbanismo/arquivo s/OUCAE_caderno_GESTAOURBANA.pdf $>$. Acesso em: 10/04/2018.

SÃO PAULO. Prospecto de Registro da Operação Urbana Consorciada Água Espraiada. Prefeitura Municipal de São Paulo, 2014. Disponível em: $<$ http://www.prefeitura.sp.gov.br/cidade/secretarias/upload/desenvolvimento_urbano/sp_urbanismo/arquivos/ cepac/oucae_prospecto.pdf $>$. Acesso em: 21/06/2017.

SARUE, Betina. "Os capitais urbanos do Porto Maravilha". Novos Estudos CEBRAP (Impresso), v. 1, 2016, pp. 78-97.

SILVA, Priscila Soares. Produção Social do Habitat na Região Portuária do Rio de Janeiro: desafios e novas perspectivas. ENANPARQ, Rio de Janeiro, 2010.

TOURINHO, Andréa de Oliveira. Centro e centralidade: uma questão recente. In: CARLOS, Ana Fani; OLIVEIRA, Ariovaldo Umbelino (orgs.). Geografias das Metrópoles. São Paulo: Contexto, 2006.

WERNECK, Mariana. Porto Maravilha: agentes, coalizões de poder e neoliberalização no Rio de Janeiro. Dissertação (Mestrado) - Instituto de Pesquisa e Planejamento Urbano e Regional, Universidade Federal do Rio de Janeiro, Rio de Janeiro, 2016. 
das obras do Morar Carioca no Morro da Providência e a reformulação do projeto de reurbanização do morro com base em amplo processo de diálogo com a comunidade. Dentre os principais argumentos apresentados pela Defensoria, alegaram-se fatores como a ausência de canais de provisão de informação à população local quanto às ações que seriam realizadas, a falta de mecanismos efetivos de participação da comunidade na definição de prioridades e no acompanhamento de sua execução, a arbitrariedade dos critérios adotados para a demarcação de casas em situação de risco, a insuficiência das ações de provisão habitacional previstas para o reassentamento da população removida e o emprego de táticas de intimidação por parte da Prefeitura para forçar moradores a aceitarem alternativas habitacionais como indenização, auxílio aluguel ou provisão definitiva em áreas distantes do local (PEREIRA, 2016). As obras do Morar Carioca no Morro da Providência foram interrompidas em virtude dessa ação judicial. Foi concedida uma liminar determinando sua paralisação em 2012, com exceção apenas da implantação do teleférico, cuja conclusão foi autorizada. 0 julgamento definitivo do mérito dessa ação ainda não ocorreu, de modo que essa disputa judicial se encontra indefinida até o momento.

O caso do Morro da Providência foi o episódio mais visível do conflito pela moradia no contexto desse projeto de "revitalização" da zona portuária. Os conflitos associados à reurbanização do morro evidenciaram o descolamento entre os discursos e as práticas presentes nesse tipo de intervenção urbanística. Ao invés da melhoria das condições urbanas e habitacionais de grupos de baixa renda, ficou claro que a real prioridade desse projeto era iniciar um processo de integração do território do Morro da Providência ao novo circuito de atrações turísticas e negócios imobiliários idealizado para a região portuária, o que tinha como um de seus componentes estratégicos a desfavelização e a pressão pela saída de segmentos sociais indesejáveis do local (SÁNCHEZ \& BROUDEHOUX, 2013; OLIVEIRA, 2015).

O contraste entre o alegado compromisso dos agentes governamentais com o atendimento de necessidades habitacionais e as práticas efetivamente adotadas no âmbito do Porto Maravilha, entretanto, não se restringiu ao caso do Morro da Providência. Conforme apontado anteriormente, tanto em disposições normativas como em falas de agentes governamentais, havia a sinalização de que seriam promovidas ações de vulto visando à permanência e à atração de um contingente significativo de moradores de baixa renda para a região. No entanto, a formulação de uma iniciativa de provisão de habitação de interesse social em escala considerável só ocorreu em 2015, seis anos após o lançamento do projeto, quando se formulou o Plano de Habitação de Interesse Social da Região do Porto do Rio de Janeiro (PHIS-Porto). Contudo, além de ter sido formulado tardiamente, esse plano não se converteu em ações concretas de provisão habitacional até o momento. 
Antes do lançamento do PHIS-Porto, as iniciativas de provisão habitacional existentes na região portuária limitavam-se aos conjuntos do Morar Carioca mencionados acima e ao Programa Novas Alternativas. Os primeiros tiveram sua construção iniciada em 2011. No entanto, as obras foram paralisadas em 2012 no contexto da disputa judicial mencionada anteriormente, de modo que não houve nenhuma unidade habitacional do Morar Carioca efetivamente entregue. Além disso, é importante frisar que tais conjuntos seriam insuficientes para absorver todo o contingente populacional a ser removido por conta das intervenções do Morar Carioca no Morro da Providência, o que faria com que tal programa tivesse um saldo numérico negativo em termos de promoção de moradia para a população de baixa renda na região. O Programa Novas Alternativas, por sua vez, já estava em curso quando se lançou o Porto Maravilha. Esse programa tem como foco a reabilitação de imóveis em situação precária na área central como um todo e sua destinação para fins de moradia com uso misto. Embora venha promovendo a reabilitação de imóveis na zona portuária e na região central, o programa tem escala muito reduzida, não produzindo impactos significativos na ampliação da oferta de moradia acessível à população de baixa renda.

Abriu-se uma perspectiva de alteração desse cenário de quase inexistência de ações de provisão habitacional em escala relevante com o lançamento do PHIS-Porto. Neste plano, cuja formulação ocorreu apenas no ano de 2015, a Prefeitura comprometeu-se a viabilizar a construção de cinco mil unidades de HIS, com indicativo da intenção de se ampliar esse montante para dez mil unidades no futuro. Embora a meta seja ousada, é importante salientar algumas ambiguidades presentes no processo de formulação desse plano. A primeira delas é a questão territorial. Definiuse que essas unidades habitacionais deveriam ser construídas prioritariamente no interior do perímetro da operação urbana, mas que poderiam se localizar na região central como um todo (a chamada "Área de Planejamento 1" do município). Essa flexibilização suscita dúvidas quanto à real intenção de se prover moradia popular em grande escala no perímetro dessa intervenção urbanística. Além disso, o plano não previu a alocação de terrenos nem de recursos financeiros para sua implementação, limitando-se a elencar esses fatores como "desafios" a serem enfrentados (PEREIRA, 2016).

O contexto em que se deu a concepção desse plano é um fator relevante para que se possa compreender a dinâmica de sua implementação até o momento e vislumbrar suas perspectivas futuras. O PHIS-Porto tornou-se objeto de debate público num momento em que a implementação do Projeto Porto Maravilha como um todo estava ameaçada por conta de uma crise da sistemática financeira estabelecida. Na modelagem que se desenhou, constituiu-se um fundo de investimento imobiliário, o FII Porto Maravilha, para intermediar a realização de investimentos por parte do FGTS 
nessa intervenção urbanística. O FII Porto Maravilha recebeu inicialmente um aporte financeiro da ordem de R\$ 3,5 bilhões do FGTS com o intuito de adquirir os CEPACs dessa operação urbana. Estabeleceu-se uma relação contratual entre o FII Porto Maravilha e a Companhia de Desenvolvimento Urbano da Região do Porto do Rio de Janeiro (CDURP), empresa municipal criada para coordenar toda a intervenção, em que o fundo adquiriu a totalidade do estoque de CEPACs, assumindo em contrapartida a obrigação de pagar os custos do contrato de parceria público-privada firmado entre a CDURP e a Concessionária Porto Novo para a realização do conjunto de intervenções previstas no projeto, cujos custos estimados eram de aproximadamente $\mathrm{R} \$ 8$ bilhões. O FII Porto Maravilha dispunha inicialmente dos R\$ 3,5 bilhões que recebera do FGTS em ativos líquidos e dos CEPACs, e tinha um passivo da ordem de R\$ 8 bilhões a ser pago ao longo do período de execução do contrato de PPP, de quinze anos. Imaginava-se que a valorização dos CEPACs daria ao fundo as condições necessárias para arcar com essas despesas (ver PEREIRA, 2016; SARUE, 2016; WERNECK, 2016).

No entanto, a dinâmica dos negócios imobiliários na região não seguiu o ritmo esperado, o que levou o Fll Porto Maravilha a uma situação de iliquidez por volta do final de 2014. A saída que se adotou para o problema foi a solicitação de um novo aporte financeiro ao FGTS, o que permitiria que o FII Porto Maravilha seguisse custeando o contrato de PPP. No entanto, paralelamente a essas negociações, houve uma mudança regulatória no plano federal exigindo que, para que uma operação urbana fosse elegível para receber recursos do FGTS, esta deveria necessariamente dispor de um plano de habitação de interesse social. Ainda que o atendimento a essa exigência possa não ter sido o único motivo por trás da elaboração do PHIS-Porto, certamente teve papel determinante para que ela ocorresse. Dessa forma, o PHIS-Porto não foi exatamente o resultado de uma decisão de política pública tomada pela Prefeitura, mas sim o desdobramento de uma exigência estabelecida na esfera federal para que se liberassem mais recursos para essa intervenção urbanística. Além disso, é importante frisar que o PHIS-Porto foi apenas anunciado, sem que tenha se convertido em ações concretas de provisão habitacional até o momento.

\section{Considerações finais}

Nos dois projetos urbanos abordados neste trabalho, observamos uma dinâmica semelhante quanto ao tratamento dado à questão habitacional. Em ambos os casos, havia forte demanda pela produção de habitação de interesse social, o que se deu tanto em virtude das remoções diretamente provocadas pelas intervenções propostas, quanto por reivindicações de movimentos de moradia e 
outros segmentos sociais organizados pleiteando maior aproveitamento dessas áreas para o atendimento de necessidades habitacionais existentes nas respectivas cidades de modo mais amplo.

No plano dos discursos e normas jurídicas, observou-se um aparente comprometimento dos agentes governamentais à frente dos projetos com a provisão de habitação de interesse social e com a promoção de outras ações de caráter redistributivo, sempre destacadas entre as supostas finalidades de tais intervenções. Na prática, entretanto, a moradia não foi tratada da mesma forma. Ações concretas de provisão habitacional para a população de baixa renda foram incipientes, não correspondendo às promessas feitas nesse sentido e ficando muito aquém do necessário para contrabalançar as remoções e os efeitos indiretos decorrentes da valorização imobiliária.

Outro aspecto crítico desses projetos no tocante ao direito de moradia diz respeito ao encadeamento das ações. Em regra, as remoções ocorreram sem que fossem antecedidas pela construção de conjuntos de HIS que permitissem a absorção da demanda de reassentamento no próprio local. Além disso, a destinação de recursos para habitação foi preterida de modo sistemático, cedendo lugar a outros investimentos tidos como estratégicos para impulsionar o processo de transformação urbanística e viabilizar a venda de CEPACs. Essa dinâmica gerou dificuldades adicionais para a provisão de HIS e a fixação da população de baixa renda no local, como o encarecimento do preço da terra, dos aluguéis e dos custos de vida em geral.

Pode-se observar também a reprodução, em pequena escala, de uma lógica centro-periferia, marcada pela segregação socioespacial, no interior das áreas de intervenção desses projetos. Nos dois casos, observou-se uma tendência a se produzir uma separação entre áreas destinadas a usos de alto padrão, nas quais ocorrem ações sistemáticas de combate a usos populares, e as áreas remanescentes, que permanecem numa espécie de limbo entre a tolerância à realidade socioespacial existente e a preparação do terreno para futuras frentes de expansão imobiliária. A pressão sobre essas áreas é condicionada pelos ciclos econômicos, intensificando-se em momentos em que o mercado imobiliário tende a se expandir e arrefecendo em períodos de recessão.

A dinâmica excludente observada nessas duas operações urbanas - ilustrada pelo tratamento conferido à questão habitacional - não decorre da mera falta de capacidade técnica ou administrativa na utilização de tal instrumento, mas de sua própria racionalidade. A necessidade de se produzir perspectivas concretas de valorização imobiliária coloca-se como critério determinante daquilo que se decide fazer ou não fazer no âmbito desses projetos. A provisão de habitação para a população pobre não apenas não contribui para que se promova o imperativo de valorização imobiliária inerente à fórmula econômico-financeira desse instrumento urbanístico, como tende a 
prejudicar tal processo. Em sentido inverso, a retirada de usos populares, especialmente no caso das favelas, tende a impulsionar o processo de valorização. Para que se legitime tais intervenções perante a opinião pública, entretanto, é preciso que seus reais fundamentos econômicos permaneçam ocultos. É precisamente esse o papel desempenhado pelas promessas de urbanização inclusiva presentes nas normativas e discursos que acompanham as operações urbanas.

Trabalho enviado em 18 de janeiro de 2019

Aceito em 28 de novembro de 2019 